Spring 4-6-2020

\title{
Implementing Protocols in the Emergency Department to Improve Care for Sexual Assault Patient
}

Kelly Ciccone

University of St. Augustine for Health Sciences, k.ciccone@usa.edu

DOI: https://doi.org/10.46409/sr.DHMS2488

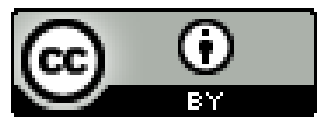

This work is licensed under a Creative Commons Attribution 4.0 License.

Follow this and additional works at: https://soar.usa.edu/scholprojects

Part of the Other Nursing Commons

\section{Recommended Citation}

Ciccone, K. (2020). Implementing Protocols in the Emergency Department to Improve Care for Sexual Assault Patient. [Doctoral project, University of St Augustine for Health Sciences]. SOAR @ USA: Student Scholarly Projects Collection. https://doi.org/10.46409/sr.DHMS2488

This Scholarly Project is brought to you for free and open access by the Student Research at SOAR @ USA. It has been accepted for inclusion in Student Scholarly Projects by an authorized administrator of SOAR @ USA. For more information, please contact soar@usa.edu, erobinson@usa.edu. 
Implementing Protocols in the Emergency Department to

Improve Care for Sexual Assault Patients

Kelly Ciccone

University of St. Augustine for Health Sciences

School of Nursing

NUR7803 DNP Practicum III

April 2020 


\begin{abstract}
This quality improvement project answered the following question: Does implementation of sexual assault forensic examination protocols with educational training increase the number of staff who are knowledgeable and available to complete sexual assault forensic examinations and reduce wait times for individuals who present to the emergency department and have indicated that they were sexually assaulted, over no use of protocols, within a 15 -week time frame? Evidence-based state protocols for performing sexual assault forensic examinations were implemented through educational training that incorporated national training criteria and handson simulation skills practice. Evaluation of outcome measures confirmed an increase to over $80 \%$ of available and knowledgeable emergency department staff for providing sexual assault forensic examinations and forensic evidence collection. Implications of the findings support the existing evidence for implementing protocols to improve the provision of examination, treatment, and forensic evidence collection for sexual assault patients. The increase in available and knowledgeable staff for performing sexual assault forensic examinations is expected to reduce the wait time for patients who present to the emergency department and report that they have been sexually assaulted.
\end{abstract}

Keywords: sexual assault forensic examination, SAFE, quality improvement, 
Implementing Protocols to Improve Care for Sexual Assault Patients

Sexual assault (SA) comprises a wide range of unwanted sexual acts, including rape, child molestation, incest, human sex trafficking, intimate partner violence (IPV), and forced sexual acts (Rape, Abuse \& Incest National Network [RAINN], 2019). These SA crimes have become a national and global epidemic (Du Mont et al., 2014). As a result, many SA patients seek help in the emergency department (ED) settings (Egyud et al., 2017). Despite the frequency of SAs, the provision of care for SA patients is often untimely and inconsistent when specially trained staff are not available (Nielson, Strong \& Steward, 2015). Delays in care may result in patients enduring long wait times or leaving the ED without being treated (Nielson et al., 2015). Florida Statutes require that hospital EDs must provide care for sexual assault patients through interprofessional services, forensic evidence collection, and staff training (Treatment of Sexual Assault Patients, FL Stat. §395.1021, 2019); however, when the required training is not provided, the lack of adequately trained staff can cause significant wait times, which may lead patients to forgo examination, treatment, and forensic evidence collection.

A lack of available and knowledgeable staff for completing Sexual Assault Forensic Examinations (SAFEs) contributed to delays in care for SA patients who presented to the practicum site. This Doctor of Nursing Practice (DNP) project proposed a practice change for implementing evidence-based protocols through educational training as guidance for completion of SAFEs in the ED of a small East Coast Florida hospital. The project increased the number of available ED staff who are knowledgeable for performing SAFEs thereby enabling patients to remain in the ED for examination and treatment. The project also provided a sustainable system for ongoing compliance with Florida statutes requiring training for ED medical support staff (Treatment of Sexual Assault Patients, Fla. Stat. §395.1021, 2019). The intervention involved an 
interdisciplinary team, including ED nurses, advanced practice nurses, physicians, physician assistants, social workers, and patient advocates. Florida state SAFE protocols were implemented to bridge a gap in staff knowledge and skills (Florida Office of the Attorney General, 2015).

\section{Significance of the Practice Problem}

Sexual assault, rape, incest, intimate partner violence, and human sex trafficking are forms of sexual abuse that happen to people of all ages, genders, races, and nationalities (RAINN, 2019). On an annual basis, over 320 thousand people over the age of twelve are raped or sexually assaulted, and over 60 thousand children are sexually abused in America (RAINN, 2019). In addition to the frequency of SA, financial impacts are also substantial. Financial considerations include costs for medical care, mental health care, and legal expenses, as well as the loss of income productivity (Tennessee, Bradham, White \& Simpson, 2017). The average lifetime financial impacts associated with SA per patient include $\$ 48,029.00$ for medical care and $\$ 63,744.00$ in loss of income productivity with additional costs of approximately $\$ 9,250$ for legal expenses (Peterson, DeGue, Florence, \& Lokey, 2017). Although costs vary based on the severity of the SA and individual patients, the Centers for Disease Control and Prevention (CDC) reported that overall annual financial impacts exceed $\$ 1.8$ billion in loss of income, and over $\$ 4$ billion in direct costs for physical and mental health for IPV (Scannell, O'Connor \& Barash, 2015). Additionally, the emotional impacts for survivors of SA may be significantly debilitating, spread to family and friends, and may be endured for years (RAINN, 2019). Despite the high frequency, complex consequences, and legal implications, the provision of care for SA patients is often untimely and inconsistent (Nielson et al., 2015). The practice problems that contribute to these problems include the absence of practice protocols and the lack of available staff who have completed training on performing SAFEs. 


\section{Timely and Effective Care}

An initial needs assessment was conducted for the project site, including a review of the Medicare.gov Hospital Compare (HC) website (U.S. Centers for Medicare \& Medicaid Service [CMS], n.d.). The Medicare.gov website included data filed in the April 24 $4^{\text {th }}, 2019$ quarterly report period. In the category of timely and effective care for the ED, the report compared the practicum site hospital ED wait times with average state and national ED wait times (CMS, n.d.). Under the category of timely and effective care, the April $24^{\text {th }}, 2019$ data indicated that the project site had an average wait time of 322 minutes, which was 60 minutes longer than the average Florida ED wait time of 260 minutes and the national average for ED wait time of 261 minutes (CMS n.d.). Data comparison also identified that the average wait time for the provision of urgent care at the facility ED was 60 minutes longer than the average state and national ED wait times (CMS, n.d.). Another care measure represented the time that patients spend waiting in the ED after a physician orders inpatient admission. An average wait time of 176 minutes for inpatient admissions from the practicum site ED was high when compared to the average Florida state wait time of 95 minutes, and the national average wait time of 92 minutes. These statistics demonstrated that the project site ED had a delay of approximately 84 minutes in getting patients admitted to the location of necessary care as compared to state and national average wait times. The third measurement of timely provision of care in the ED was the length of time patients must wait before being provided with pain medication. The data reflected that the project site had an average wait time of 58 minutes for pain medication administration, which is a delay of 12 minutes in pain management as compared to the average state ED wait time of 46 minutes. When considering the number of patients who leave the ED before being seen or treated, the top $10 \%$ of hospitals scored zero percent. However, the report showed that approximately $1 \%$ (or 
227 patients) left the project site ED before being seen or treated (CMS, n.d.). These findings identified an opportunity for improvement in the area of timely and effective delivery of care in the ED.

\section{Gap Analysis}

A gap analysis was completed in follow-up to the needs assessment to determine the cause for the practicum site ED wait times being higher than the average state and national ED wait times. Links between delayed care and gaps in staff knowledge, skills, and practices were considered. Contributing factors to ED wait times included a gap in staff knowledge and skills for performing Sexual Assault Forensic Examinations (SAFEs). An absence of procedural protocols and lack of staff education and training on the topic of providing SAFEs resulted in the limited availability of ED nurses who were knowledgeable for performing SAFEs. Du Mont, Solomon, Kosa, and Macdonald (2018) explained that ED staff are often not adequately trained to provide the unique and complex care required for SA patients. When trained staff are not readily available, SA patients must wait in the ED for a specialty trained Sexual Assault Nurse Examiner (SANE) trained staff to be called to come to the ED for completing the SAFE and for collecting forensic evidence. In addition, Dumont et al. (2018) established that untrained staff often miss crucial aspects of the examination and evidence collection. A review of these findings resulted in a determination of the need for initiating a quality improvement practice change to improve timely and effective ED initiation of SA examinations.

\section{Framework of the Problem}

The organizational readiness for practice change was established, and leadership support was obtained. After considering several theoretical frameworks, Kotter's change management theory was selected for this project because it is a well-established and effective approach for 
organizational change (Pollack \& Pollack, 2015). Kotter's contemporary change theory includes a straight-forward approach with eight steps for guiding change in organizations (White, DudleyBrown, \& Terhaar, 2016). Also, Kotter's theory is considered the most compelling method for effective management of change (Pollack \& Pollack, 2015). According to Maclean and Vannet (2016), Kotter's theory successfully guided the implementation of protocols for trauma computed tomography (CT) in several ED locations.

Kotter's theory aligns with the organization's dedication to providing the highest possible level of care and served as the framework for this DNP project. The project began with a review of SA patients' needs, regulatory requirements, and provider responsibilities to initiate a sense of urgency for practice change. An interprofessional team alliance was established, including registered nurses, advanced practice nurses, physicians, advocates, and pharmacists, as well as information technology (IT) personnel. A shared vision for the project was developed and served to unite efforts for increasing the number of available and knowledgeable staff for completing SAFEs. Next, evidence-based protocols were implemented to eliminate barriers, and the protocols empowered nurses with the knowledge and skills necessary for performing SAFEs. Short-term wins were celebrated during the completion of training sessions to maintain project enthusiasm and perseverance. Once protocols were successfully implemented in the ED, evaluation began. Next, sustainability efforts were initiated to embed the practice into organizational culture, including new employee orientation and annual education schedules. Additionally, project dissemination plans began upon project closure.

\section{Scholarly Question}

Does the implementation of sexual assault forensic examination protocols through educational training increase the number of staff who are knowledgeable and available to 
complete SAFEs and reduce wait times for individuals who present to the emergency department who have indicated that they were sexually assaulted, over no use of protocols, within a 15 -week time frame?

\section{Population}

According to (RAINN 2019), sexual assault victims include victims of rape, incest, intimate partner violence, and human sex trafficking. The population for this project is individuals who present to the ED, indicating that they have been sexually assaulted. These individuals require a unique combination of clinical and forensic services (Auten et al., 2014). Cochran (2019) studied the provision of care for sexual assault patients and found that this population frequently experiences psychological trauma and often requires mental health care. Furthermore, this study revealed that the risk of suicide for individuals who have been sexually assaulted is increased by ten times, and $45 \%$ of rape patients have ideas of suicide, with $23 \%$ of rape patients attempting suicide. Also, the care for this population requires time-sensitive clinical and forensic services. For example, the effectiveness of prophylactic medications for preventing pregnancy is dependent on early medication administration. Additionally, this population requires the timely and accurate collection of forensic evidence (Du Mont et al., 2018). These considerations demonstrate the importance of having available and knowledgeable ED staff for performing SAFEs and minimizing the wait time for the SA population (Du Mont et al., 2018).

\section{Intervention}

The proposed intervention began with initiating interest and developing an interprofessional project team. The project team included ED nurses, advanced practice providers, physicians, pharmacists, nursing management, IT personnel, patient advocates, and trained SANE's. Collaborative discussions with interprofessional team members provided a 
comprehensive and useful network for project implementation. Interprofessional input enabled planning and scheduling for protocol implementation with staff education and training on the provision of SAFEs. Implementing the state of Florida SAFE protocols increased the number of available and knowledgeable ED staff for completing SAFEs and also increased the consistency of care by providing an evidence-based resource to guide staff practice (Florida Office of the Attorney General, 2015). The Florida SAFE protocols were implemented through staff education and skills training sessions that included the U.S. Department of Justice minimum training recommendations for all personnel who provide care for SA patients, (U.S. Department of Justice, 2018). Training content included primary medical evaluation and stabilization, completion of the SAFE, collection, and management of forensic evidence, documentation, court testifying, and interprofessional practice (U.S. Department of Justice, 2018).

\section{Comparison}

At project onset, the facility had only one available staff nurse who had been trained to complete SAFEs, and the facility had no protocols to guide staff for performing SAFEs. Furthermore, the hospital had no training program to educate staff on completing SAFEs. This was significant because, at the onset of this project, the facility practice contributed to the lack of available and knowledgeable ED staff for meeting the needs of sexual assault patients in a timely manner. The baseline practice also contributed to the CMS Hospital Compare reports of ED wait times that exceeded the state and national average wait times (CMS, n.d.).

\section{Outcome}

The intended outcome was an increased number of available and knowledgeable ED nurses for performing timely SAFEs for sexual assault patients to at least $80 \%$ of ED nursing staff and to reduce ED wait times to 30 minutes or less for initiation of SAFEs. Du Mont et al. 
(2018) reported that the introduction of a SA response program resulted in a reduction in ED wait times from 30 minutes to 22 minutes as well as increased effectiveness in the collection of forensic evidence. Evidence from the literature demonstrated the potential to achieve a reduction in ED wait times through protocol implementation. According to the HC, the hospital ED had an average wait time of 322 minutes, and an average of $1 \%$ of patients left the ED waiting room without being seen or treated (CMS, n.d.). Based on these statistics and supporting evidence from the literature, an outcome goal was established to initiate the SAFE within 30 minutes of a SA patient registering at the ED. The medical clearance evaluation will continue to be prioritized and completed before the SAFE.

\section{Timeline}

The project timeline was approximately 15 weeks and included several strategies for increasing the number of available staff who have the knowledge and skills necessary for completing SAFEs. During the first week, a clear understanding of the project scope, the project vision, the timeline, and team member roles were reviewed, and an effective communication system was established. Communication included email for status updates and routine meetings with the ED director. The project was monitored weekly to ensure the timely provision of key deliverables. Implementation began after the university review board approved the project.

\section{Literature Search Strategy}

A review of the literature began with an electronic search of databases, including the Cumulative Index to Nursing and Allied Health Literature (CINAHL), Ovid, and PubMed. The keywords used in the search process include sexual assault, violence, abuse, forensic examination, emergency department, and emergency room. The search limited the report-type to peer-reviewed academic journals, in the publication English language, and within the timeframe 
January 1, 2014 to present date July 2019. Additional limiting criteria were applied to increase relevancy by using the terms of timely care, implementation, and quality. Articles were screened to verify that the patient population included patients of SA, rape, sexual abuse, sexual violence, IPV, or human sex trafficking and that the health care setting was a hospital ED or emergency room. Next, a review of the articles excluded SA preventive measures, community health, secondary sources, and summary articles. The final literature review included a thorough evaluation and comparison of 25 articles to identify evidence-based interventions for improving timeliness and effectiveness of care for patients of SA, sexual abuse, human sex trafficking, and intimate partner violence. Synthesis of the literature identified reliable and consistent evidencebased support of four meaningful themes, including recommendations to implement SAFE protocols, provide specialized education, conduct skills training, and utilize interprofessional collaborations. The main themes found in the literature were also compared with national protocols, regulations, position statements, and accreditation standards. A summary of primary resources (see Appendix A) and systematic reviews (see Appendix B) include themes of providing staff education, conducting staff training, implementing SAFE protocols, and using interprofessional collaboration.

\section{Literature Search Results and Evaluation}

The online search resulted in 52 citations from CINAHL, 36 citations from ProQuest, and 40 citations from PubMed for a total of 128 citations. The total number of articles was reduced when duplicate articles were excluded. Also, articles that focused on the population of pediatric sexual assault patients were excluded. Articles on the subject of preventing sexual assault and community preventive initiatives were also excluded. 
The remaining 25 articles were reviewed for level and quality by using the Johns Hopkins Nursing Evidence-Based Practice Level and Quality Guide (Dearholt, \& Dang, 2012). The articles included a combination of four good quality articles and 21 high-quality articles specific to the PICOT question. The breakdown of article levels included three level I high-quality articles, one level II high-quality article, nine level III high-quality articles, one level IV good quality article, one level IV high-quality article, three-level V good quality articles, and sevenlevel V high-quality articles. Appendix A provides a listing of primary resources, and Appendix B provides a list of systematic reviews, including the level and quality of evidence-based support articles. The quality and level of the supportive literature were sufficient to categorize the recommended intervention as a level 1 practice change recommendation.

\section{Themes from the Literature}

The main themes found in the literature were compared with national protocols, regulations, position statements, and accreditation standards. A summary of the primary resources that includes the level and quality of evidence-based support can be found in Appendix A, and systematic reviews are listed in Appendix B. The Johns Hopkins Evidence Level and Quality Guide was used for identifying high-quality, evidence-based resources from peerreviewed journals. The literature included themes of providing staff education, conducting staff training, implementing SAFE protocols, and using interprofessional collaboration, which will be discussed individually.

\section{Staff Education}

The most frequently cited intervention for improving care for SA patients was the provision of specialized education to bridge the gap in staff knowledge and skills. Multiple resources agreed on recommendations to provide education for ED staff on the topic of providing 
care for patients of sexual violence (Adams \& Hulton, 2016; Auten et al., 2015; Blumling, Kameg, Cline, Szpak \& Koller, 2018; Cochran, 2019; Donahue, Schwien, \& LaVallee, 2019; Du Mont et al., 2018; Egyud et al., 2017; Gilles et al., 2019; Greenbaum, Livings, et al., 2018; Hemmings et al., 2016; Jina, Jewkes, Christofides, \& Loots, 2014; Jordan et al., 2019; Marchetti, Fantasia, \& Molchan, 2014; Marks, Kaiser, \& McCleery, 2017; Nielson, Strong, \& Stewart, 2015; Patterson \& Resko, 2015; Rogers et al., 2019; Scannell, Lewis-O’Connor, \& Barash, 2015; Scannell, MacDonald, Berger, \& Boyer, 2018; Tozzo, Ponzano, Spigarolo, Nespeca, \& Caenazzo, 2018; Whalen et al., 2018; Witt et al., 2015; Yildiz, Selimen, \& Dogan, 2014). It is significant to note that including education and training along with the implementation of other strategies such as protocols was increased impacts and positive outcomes.

Recommendations for implementing education were also reflected in the Emergency Nurses Association (ENA), and the International Association of Forensic Nursing (IAFN) joint position statement that supports staff education on the provision of care for SA patients in the ED (ENA, 2019). Additional support for specialized educational training was noted by the National Institute of Justice (NIJ; 2017), who recommended specialized training for ED nursing staff on the subject of caring for SA patients. The NIJ provided curricular content including the neurobiology of trauma, the role of multidisciplinary collaborations, the SAFE process, documentation, medication management, discharge plans, follow-up plans, the security of records, and testifying in court (NIJ, 2017). This content is essential because it encompasses the minimum necessary educational components identified by the national standards for ED education on the subject of caring for SA patients (Department of Justice, 2017).

Presentation of the curriculum included a lecture, written reference material, and handson simulation skills practice. Several approaches for providing specialized education were 
presented in the literature, including the benefits of using simulation to support education (Blumling et al., 2018; Jina et al., 2014; Marks et al., 2017; Scannell et al., 2015; Scannell et al., 2018; Witt et al., 2015). For example, a study by Blumling et al. (2018), found that including simulation in the education of nursing students is useful to increase knowledge and confidence in caring for patients of intimate partner violence. Similarly, Marks et al. (2017), discussed a creative strategy to incorporate simulation to streamline the educational process for timely and efficient education completion. These studies provided specific, replicable, and meaningful applications of educational tactics to increase staff competency and improve care for patients who have been sexually assaulted.

\section{Skills Training}

In addition to indicating the need for specialized education on the subject of SAFEs, the literature also supported skills training as another means for reinforcing and integrating knowledge into practice (Giles et al., 2019; Jordon et al., 2019). Furthermore, patients of SA require specialized nursing care that includes a unique combination of clinical and forensic skills (Giles et al., 2019). Evidence from the literature also establishes that the addition of forensic skills training improves staff competency in areas such as examination, collaboration, evidence collection, security, photography, documentation, and the responsibility and expectations of being a witness (Adams \& Hulton, 2016; Auten et al., 2015; Egyud et al., 2017; Marks et al., 2017; Witt et al., 2015). According to Morse (2019), skills training reinforces the knowledge that staff members learn during the educational sessions.

Moreover, skills training is vital to ensure that staff can apply the knowledge that they learned during educational lectures. For example, Bush (2017), reiterated the ENA and IAFN joint position in support of combining clinical and forensic education with skills training. This 
position also asserted that hospital EDs must acknowledge obligations to provide comprehensive medical care and forensic interventions for SA patients, even when the facility may not have an established SANE program (ENA, 2019). According to Adams and Hulton (2016), education combined with training equips nurses with knowledge and skills necessary for the provision of comprehensive, prompt, and trauma-informed care. Forensic training prepares nurses with a unique combination of clinical skills and forensic evidence collection skills, which is crucial for patient care as well as prosecution.

\section{Implementing Protocols}

Evidence from the literature supported the implementation of SAFE protocols that improved staff knowledge and skills for completing timely and effective SAFEs (Campbell et al., 2015; Cochran, 2019; Du Mont et al., 2014, 2018; Egyud et al., 2017; Gilles et al., 2019; Greenbaum, Titchen, et al., 2018; Hemmings et al., 2016; Nielson et al., 2015; Scannell et al., 2015, Schannel et al., 2018; Tozp et al., 2018; Whalen et al., 2018). The ENA and the IAFN joint position statement supported the use of protocols by saying that SA patients should receive consistent and immediate care in addition to having the option for forensic evidence to be collected by ED nurses and physicians who are knowledgeable of guidelines and protocols for evidence collection (Bush, 2017). The ENA and IAFN joint position statement said that emergency nurses should have ongoing education about SAFEs, and they should also have access to legislative guidelines and protocols on appropriate examination and reporting (ENA, 2019). The Florida SAFE protocols addressed the rights and needs of SA patients, as well as the examination process, the evidence collection process, and the chain of custody for evidence (Treatment of SA Patients, Florida Statutes $§ 395.1021,2019)$. For these reasons, this project implemented the state of Florida protocols for the provision of care and services for SA patients 
(Florida Office of the Attorney General, 2015). Furthermore, the Florida SAFE protocol implementation addressed the standards from the Joint Commission on Accreditation of Healthcare Organizations, which call for ED staff training on policies for assessing SA patients (U.S. Department of Justice, 2018).

\section{Interprofessional Collaboration}

Another trend that was identified in the literature was the importance of using a collaborative interprofessional approach to the provision of care for SA patients (Adams \& Huton, 2016; Eguyd et al., 2017; Jordan et al., 2019). This type of approach is useful for ensuring the provision of care for the complex needs of SA patients. Adams and Hutton (2016) explained that ED personnel should develop strategic partnerships for collaborating with the local Sexual Assault Response Team (SART); therefore, networking and relationships were initiated between the facility and community resources. The SART members include patient advocates who assist SA patients throughout the process, and each SA patient is entitled to have a patient advocate. It will be essential to offer patient advocate services to SA patients and arrange for advocates to participate in the SAFE process. Other SART members include resources for social services, mental health services, counseling, and legal services. The patient's advocates coordinate SART services based on the individuals' needs. Social services also assist with local resources, including counseling and support groups. Mental health resources may be involved in addressing depression or suicidal risk factors as needed. Legal representatives may be included in the prosecution, depending on the details of the event. Bush (2017), pointed out that the ENA and IAFN combined joint position statement indicates collaboration between the ED nurse, the patient, social services, medical providers, advocacy centers, law enforcement, and other resource agencies is necessary for optimizing care for SA patients. Also, the NIJ (2017) 
concurred with the necessity of implementing a multidisciplinary approach using the national best practices for completing SAFEs. For these reasons, this project incorporated a collaborative interprofessional approach for implementing Florida protocols through staff education and training on the subject of performing SAFEs.

\section{Practice Recommendations}

A thorough review of the literature answered the PICOT question by establishing that the implementation of SAFE protocols is useful for increasing the number of available staff who are knowledgeable for performing SAFEs and decreasing wait times when compared to no use of protocols (Egyud et al., 2017). The Johns Hopkins Nursing Evidence-Based Practice Level and Quality Guide was used to verify the quality and level of evidence-based literature that identified and supported the practice change recommendation (Dearholt, \& Dang, 2012). Based on conclusions drawn from a synthesis of evidence found in the literature and supportive state regulations, the practice change recommendation included the intervention of implementing the Florida state protocols for performing SAFEs through the provision of staff education and skills training (Florida Office of the Attorney General, 2015).

Internal project validity was ensured by considering the degree to which the dependent variable, which was the intervention of implementing protocols through staff educational training, explained changes in the independent variable, which was the number of available and knowledgeable staff for performing SAFEs and reducing the ED wait time. Routine project management included identifying and controlling threats to internal validity. Ongoing collaboration with the director of education and ED director determined that were no newly hired ED staff who were knowledgeable for performing SAFEs, and no confounding or extraneous variables occurred. 
Limitations for the project included the budget, timeframe, staffing and lack of control over the number or type of patients who may present to the ED for care. Close project management was successful to maintain the allocated budget and complete the project within the designated timeframe. Balancing measures successfully managed the need to maintain adequate ED staffings by scheduling multiple small groups for educational training sessions. The evaluation of ED wait times for sexual assault patients was limited because no sexual assault patients presented to the ED for examination during the evaluation timeframe.

Staff education and skills training sessions were used to implement Florida state protocols and were comprised of the minimum required training content as established by the U.S. Department of Justice (U.S2018). ED staff who are involved in the provision of care for SA patients were invited and encouraged to participate in educational training. A list of scheduled educational training sessions was posted at the ED to allow ED staff members to select and signup for their preferred participation times. The educational training incorporated a variety of teaching and learning strategies, including verbal presentation, visual reference material, interactive demonstrations, and simulated skills practice with return demonstrations. Multiple educational training sessions were provided to increase attendance. The strategies of removing distractions, ensuring adequate lighting, and maintaining a comfortable room temperature were used to optimize staff learning. Evaluations determined that the practice change increased the number of available and knowledgeable staff for providing SAFEs. It is also expected to improve the timeliness and quality of patient care while achieving compliance with state regulations that require training for ED staff on the provision of care for sexual assault patients (The Florida Senate, 2018). 
Implications of the project results support previous findings that demonstrate implementation of guidelines with educational training is effective for increasing the number of available and knowledgeable ED staff for performing SAFEs (Dumont, et al., 2018). In consideration of the positive outcomes, recommendations include replicating the project at a sister hospital. Replicating the project will provide an opportunity for lengthening the evaluation timeframe to enable evaluation of a reduction in wait times for sexual assault patients. Suggestions for next steps related to the practice problem include developing an advanced educational training program with a goal promoting staff certification in addition to adding SAFE skills reviews to the facility annual skill check fair.

\section{Project Setting}

The setting for this DNP scholarly project was the ED of a small 154-bed community hospital on the East Coast of Florida that is part of a more extensive parent health care network. The hospital provides level one adult cardiovascular service, tertiary care for bariatric surgery, transitional rehabilitation care, stroke care, general hospital care, and urgent/emergency care. The typical clients are adults seeking cardiovascular, stroke, bariatric, and emergency care; however, patients of all ages are seen in the ED for urgent care needs.

The hospital focuses on using care and compassion to provide the highest achievable level of health care. Their mission statement commits to reaching the highest measurable level of efficient quality health-care delivery in response to the patient, provider, staff, and visitor needs and values. Details about the organizational structure, organization culture, needs assessment, stakeholders, project support, project sustainability, and the analysis of facility strengths and weaknesses will be discussed separately. 


\section{Organizational Structure}

The practice site is part of a much more extensive health care network. The integrated health care model includes multiple health care settings such as hospitals, long-term care nursing centers, urgent care centers, and specialty care facilities. This facility is one of the 36 hospitals in the organization. The business model includes being the leader in low-priced, high-quality health care. The organizational structure consists of a top-level Chief Executive Officer, and mid-level Chief Financial Officer, Chief Operating Officer, and Chief Nursing Officer (CNO). The next level includes department directors with managers and direct care staff in each department.

\section{Organizational Culture}

The beliefs and practices of personnel who work within the project site demonstrate a culture of quality, care, and accountability (Sebastian River Medical Center, n.d.). Cultural diversity is shown in a variety of terms used to describe a sexually assaulted person. Clinicians use the term patient, advocates, law enforcement use victims, and social workers or attorneys frequently use the term client (Adams \& Hulton, 2016). The organization supports the culturally diverse needs of patients, staff, and providers and promotes patient-centered care.

\section{Organizational Need}

An organizational needs assessment was completed and indicated a need to reduce the ED wait time (CMS, n.d.) and warranted the completion of a gap analysis that identified a gap in staff knowledge, a gap in staff skills regarding the provision of care for SA patients, and a lack of practice protocols. The hospital confirmed that only one ED staff member had completed specialized training for completing SA examinations with forensic evidence collection. The needs assessment and gap analysis identified the need for implementing practice protocols through educational training and interprofessional collaborations. 


\section{Stakeholders}

A tool called the "Key Stakeholder Dance" was used to identify key stakeholders. The D.A.N.C.E. acronym represents decisions, authority, need, connections, and energy. The identified stakeholders included the ED director for decisions, the chief nursing officer for authority, nursing staff representatives for needs, the IT manager and education director for connections, and a staff nurse for energy (Kogon, Blakemore, \& Wood, 2015). Additional stakeholders included patients, family members, nurses, physicians, physician assistants, advanced nurse practitioners, social services, pharmacy, billing staff, local law enforcement, and the local SART team.

\section{Organizational Support}

Organizational support was initially provided by the CNO and the project preceptor. The director of education and ED director also confirmed support during initial meetings. Also, the ED staff were encouraged to provide input and generated support for this project. Early involvement of staff was a driving force for increasing staff buy-in and establishing effective communication, as was recommended by Kogon et al. (2015).

\section{Sustainability}

Sustainability is a foundational element of long-term project success. Sustainability of the practice change for following Florida's protocols on SAFEs was achieved by identifying and supporting project champions as recommended by Lawson et al., (2018). Critical areas for the sustainability of this practice change include culture for improvement with staff engagement, robust feedback, and change structure, as suggested by Lawson, Weekes, and Hill (2018). A repeatable educational training program and reference protocols were based on interprofessional collaborations with the ED director, education director, director of nursing services, and project 
preceptor to maintain and sustain the project as recommended by Lawson et al. (2018). To further sustain the use of Florida protocols on SAFEs, materials were provided to include in the orientation education for newly hired ED staff as well as ongoing continuing education for existing staff. Integrating the SAFE protocols into the existing ED reference book provided ease of access for staff reference practice sustainability. Also, recommendations were made for the facility to further increase SAFE protocol sustainability by incorporating ongoing updates of the electronic health record for SAFE documentation.

\section{Interprofessional Collaboration}

A foundational aspect of this project involved interprofessional collaboration to provide comprehensive care for SA patients with input from physicians, physician assistants, advanced practiced nurses, registered nurses, pharmacists, and community resource support as needed. Medical screening, examination, and provision of urgent care remain the priority, and interprofessional team members continue to work together for coordinating the provision of medical care with emotional needs and forensic evidence collection. For example, when the medical screening examination requires the SA patients to remove clothing, the team coordinates care for clothing removal and preservation of forensic evidence for proper collection. In keeping with recommendations from Adams and Hulton (2016), the facility was encouraged to continue building a collaborative relationship with the local SART for coordination of patient follow up needs with community resources.

\section{Strength, Weakness, Opportunity and Threat Analysis}

A strength, weakness, opportunity and threat (SWOT) analysis was completed to identify general baseline information about the facility readiness and abilities for implementing change. Key strengths included leadership support, staff interest, facility values equipment availability, 
and an active education program. Weaknesses included challenges for scheduling staff participation in educational training, a lack of educational training material, a limited number of available staff who had completed SANE training, and absence of policies, procedures, guidelines, or protocols. The hospital had an opportunity to schedule multiple training options, and to network with the local SART for support. Staff turnover was a primary threat that required an ongoing program to maintain adequate levels of available, knowledgeable staff for performing SAFEs to prevent SA patients from leaving the ED before the SAFE is completed and treatment is provided. Appendix C offers a full depiction of the SWOT analysis.

\section{Project Overview}

The mission, vision, and objectives of this project helped with the effective communication of project purpose, maintenance of the team focus, and management of the schedule. The project vision indicated the desired future practice, while the mission focused on current processes and why they exist. The project objectives included decreasing the ED wait time to encourage SA patients to remain in the ED for the completion of a SAFE examination and treatment. This was accomplished through short-term goals and objectives. Long-term goals will sustain the project intervention by embedding the protocols and educational training into new hire orientation and ongoing annual continuing education. An unintended but positive consequence for the project included motivating ED nurses to pursue more extensive training and SANE certification, which also occurred in a study by Marks et al. (2017). According to Kogan et al. (2015), it is not possible to remove all risks; however, preliminary efforts were made to anticipate and eliminate or mitigate potential risks to the extent possible. 


\section{Project Vision and Mission}

According to Christenson and Walker (2004), the vision statement drives project success. Part of the change process included establishing and communicating the project vision. The vision for this project was fully implemented evidence-based SAFE protocols that enable the timely provision of SAFEs to meet the needs of SA patients. The integration of protocols and educational training provided a sustainable solution to the problem of limited availability of staff who are knowledgeable about performing SAFEs. The mission for this project was to increase the number of staff who are available and knowledgeable to perform SAFEs in a timely manner by implementing and integrating evidence-based SAFE protocols. The protocols include patient education, examination, diagnostic testing, prophylactic medication, forensic evidence collection, coordination of follow up care, documentation, and participating in legal proceedings as necessary. The project mission aligned with the hospital's mission of providing the highest measurable level of quality healthcare.

\section{Objectives}

An objective of this project was to reduce the ED wait time, therefore, increasing the number of SA patients who complete their SAFE examination, receive treatment, and access resources. A related short-term objective was that $95 \%$ of SA patients who present to the ED would be seen for initiation of the SAFE within 30 minutes of ED registration by the 15 th week of the project. It is important to differentiate that medical screening, examination, urgent clinical treatment, and clearance are prioritized. Short and long-term objectives will be discussed in the following sections. 


\section{Short-Term Goals}

A short-term goal was to increase the number of ED staff who are available and knowledgeable for performing timely SAFEs to at least $80 \%$ of the ED nursing staff by week 15 of the project. Another short-term goal was to increase the number of ED nurses who have completed education and training about the Florida state SAFE protocols to at least $80 \%$ of the ED nursing staff within four-weeks of educational training sessions (Florida Office of the Attorney General, 2015). Completion of each education and training session resulted in each participant achieving the ability to answer at least $80 \%$ on a post-education test accurately. The next short-term goal was to increase the number of ED nursing staff who can demonstrate at least seven SAFE skills to at least $80 \%$ of available ED nursing staff. This goal was achieved as each participant demonstrated the ability to perform seven or more SAFE skills by the completion of the skills training sessions.

\section{Long-Term Goals}

There were several long-term goals for this project, including increasing the number of ED nurses available and knowledgeable for performing SAFEs to at least $80 \%$ and reducing the average ED wait time for sexual assault patients to no more than 30 minutes. Related long-term goals for practice sustainability included increasing the number of newly recruited ED nurses who complete education and training about SAFE protocols during employee orientation to $95 \%$ within three months after project initiation and initiating annual review training sessions on SAFEs within one year of project initiation. The purpose of these goals was to sustain a system for maintaining the availability of ED staff who are knowledgeable to provide SAFEs in a timely and accurate manner according to regulations, standards, and protocols by embedding project practices in the facility quality improvement culture. 


\section{Unintended Consequences and Risk Factors}

While unintended consequences are typically viewed as unfavorable, in this scenario, a positive result of the project included motivating ED nurses to pursue more extensive training and formal SANE certification. Although there was no more than minimal potential for patient risk, patient safety remained a priority. Possible risks included ineffective communication, staff resistance to change, delayed care, challenges in scheduling education sessions, and potential for conflicts or ineffective interdisciplinary collaboration. Preliminary recognition of these risks provided the opportunity to establish an effective system of communication, including status update meetings and e-mail, which minimized risks for ineffective collaboration or conflicts. Collaborating with the ED director and education director, as well as planning for multiple options for educational training times, were useful to minimize the potential risk of conflicts in scheduling staff for attending training sessions. Markes et al. (2017) noted tactics to mitigate the potential for resistance to change, such as involving staff in the project, acknowledging achievements and celebrating success, which was effectively incorporated into this project.

Another focus risk related to this project was that the nursing staff might experience vicarious trauma (VT). According to Raunick, Lindell, Morris, and Backman (2015), nurses and other healthcare providers who experienced repetitive exposure to high stress and traumatic types of patient care, such as caring for patients of SA, are at risk for developing VT. Personnel who provide care for patients who have survived SA events are exposed to hearing graphic reviews of the assault in addition to visual exposure to related physical injuries (Raunick et al., 2015). Preliminary awareness of this potential risk identified the need to incorporate resources to minimize negative impacts. Raunick et al. (2015), advised that debriefing and interdisciplinary 
collaborative approaches to patient care are useful to reduce VT. Therefore, those tactics were incorporated in project implementation (Raunick et al., 2015).

\section{Project Description}

Kotter's change model guided the planning for this project, and it was selected because it has been identified as an empirically sound process with a sequence of steps designed for effectively implementing change (Baloh et al., 2018). Also, the Plan Do Study Act (PDSA) model was selected for this project because, according to DeAnda (2018), it has previously been used for implementing a change process that expedited the timeliness of throughput in similar ED settings. The combination of a useful change model with a practical implementation model was beneficial for the successful implementation of practice change. The plan included the identification and management of barriers and facilitators. Timeframes for completing key deliverables were established to ensure timeliness.

Additionally, the project incorporated financial and budgetary considerations, including estimated costs and revenue. To complete this project and achieve the objectives, the role of the project manager required a variety of leadership qualities and skills, as well as interprofessional collaboration and support. The Agency for Healthcare Research \& Quality ([AHRQ] 2013), describes the PDSA model, which was incorporated with Kotter's change model to include evaluation of the project's strengths and weaknesses during implementation. This process will be discussed in the change model review.

\section{Kotter's Change Model}

Kotter's model has been demonstrated as a useful and practical guide for implementing protocols in several ED settings, which were similar to the location and intervention for this project (Baloh et al., 2018). For these reasons, Kotter's model was appropriate for this project. 
The eight-step model was used to plan and describe the recommended practice change and how the change would be implemented. According to Lock (2018), Kotter's model includes:

1. Establishing urgency.

2. Creating a guiding coalition.

3. Developing a project vision.

4. Communicating the vision.

5. Removing obstacles and empowering actions.

6. Developing short-term wins.

7. Consolidating and moving forward

8. Anchoring the new practices (Lock, 2018).

Establish a sense of urgency. In keeping with Kotter's model and the PDSA model, the initial planning phase began by establishing a sense of urgency for implementing the Florida state protocols on completing SAFEs (DeAnda, 2018, Pollack \& Pollack, 2015). A review of patient needs, state regulations, accreditation standards, and related quality measures were discussed and compared to the current facility practice to generate a sense of urgency. Baseline practice data was used to demonstrate the problem and the need for implementing a practice change. The Florida state protocols on completing SAFEs were shared to stimulate interest and enthusiasm about bridging the gap between the baseline and the desired practice while also addressing compliance with state requirements and Joint Commission standards (Florida Office of the Attorney General, 2015).

Create a coalition. A supportive interprofessional alliance was initiated by the second week of the project and served as a vital component of the project's success. Initial efforts included collaborations with key personnel who have the power, desire, and ability to assist in 
moving the project forward (Pollack \& Pollack, 2015). The CNO and the ED director are essential team members because they have the power and authority to make decisions and overcome barriers. The ED director provided a leadership presence, project support, and accountability. The director of education was instrumental in coordinating and planning educational training. The pharmacist verified that order sets reflect current recommended medication management to address potential pregnancy or sexually transmitted infections (STIs). IT personnel managed electronic health record needs. Social workers and patient advocates coordinated access to local resources. Physicians, advanced practice nurses, and registered nurses collaborated to organize the provision of medical screening, medical care, forensic examination, and evidence collection. Also, informal leaders who demonstrated enthusiasm served as project champions to motivate other staff. Lock (2018) noted the value of maintaining visible support by holding project status meetings with leadership and recognizing project progress. These strategies were implemented by providing status update sessions with ED leadership.

Develop a project vision. A clear vision of how the facility would practice after the project implementation provided support for implementing the practice change (Lock, 2018). The vision was established during stakeholder team meetings in the first week of the project. A fishbone diagram was posted in the training room to obtain input from ED staff to identify staff needs, increase involvement, and increase buy-in. The intended vision was fully implemented evidence-based SAFE protocols that enabled nurses to provide timely SAFEs to meet patients' needs.

Communicate the project vision. The project vision was shared during department meetings to ensure stakeholders, project team members, and staff members have the same understanding of the project scope and share a common goal (Lock, 2018). Communication 
included information about the reasons for implementing Florida State protocols on completing SAFEs (Florida Office of the Attorney General, 2015). Weekly department meetings, shift huddles, and email were used to share the vision and for ongoing communication.

Remove obstacles and empower staff to take action. Kotter's fifth step, as applied to this project, included the elimination of obstacles that may have gotten in the way of progress (Kogan et al., 2015). For early identification and mitigation of barriers, a risk matrix tool was completed with input from staff and the project team by the second week of the project, and high-level risks were prioritized. For example, preliminary planning predicted scheduling conflicts that might be a barrier for staff attendance at training sessions. To address this barrier, multiple educational training sessions were scheduled for all shifts, including weekends, over a four-week time frame. Weekly project monitoring and open communication were used for prompt identification and resolution of any obstacles as they occurred. Minimizing barriers enabled and empowered staff to take the necessary actions that reflected the "do" section of the PDSA model (DeAnda, 2018). The ED staff were encouraged to participate in educational training that included an interactive approach to facilitate empowerment (Pollack \& Pollack, 2015). Also, hands-on simulation practice and demonstrations enabled and empowered staff to take actions by increasing staff competency and confidence (Scannell et al., 2015). The PDSA model included studying the intervention and identification of any weaknesses that could require project modifications before the next cycle (DeAnda, 2018).

Develop short-term wins. The project plan included breaking down the process into sections, so it did not appear to be insurmountable and to encourage buy-in for implementing change. The PDSA model was helpful in this stage for breaking down the task into steps that were then measured, evaluated, modified if necessary, and celebrated (DeAnda, 2018). Project 
progress was documented on a run chart, which was a tactic that was also effectively used by Joshi, Ransom, Nash, and Ransom (2008). For example, the number of staff who completed the education and training each week were plotted on a run chart to provide a visual demonstration and celebration of progress.

Consolidate and continue moving ahead. Weekly updates about the project progress and accomplishments, as well as actions planned for the upcoming week, were communicated through email and meetings to maintain focus and motivation. For example, as more staff completed the education and training on Florida SAFE protocols, the number of available personnel for performing timely SAFEs increased, which is expected to decrease the wait time for SAFE initiation. Consolidating these gains included the demonstration of highlights of the previously mentioned short term wins to persuade stakeholders to commit to moving ahead with embedding the SAFE protocol practice into routine organizational culture (Tanner \& Tanner, 2019).

Anchor new practice. A copy of the revised 2015 "Adult and Child Sexual Assault Protocols: Initial Forensic Physical Examination" was provided to the facility to facilitate embedding the practice change into routine facility culture (Office of the Attorney General (2015). Also, a transition in communication phased out references to the term 'project' by referring to the facility protocols instead. To further integrate and promote sustainability, the Florida state protocols for SAFEs, as well as the education and training outline, were provided for incorporation into the orientation process for newly hired ED staff. Locke (2018) commented on the need for ongoing training to ensure staff members remain current with knowledge and skills, which was incorporated by recommending that SAFE training should be added to the ED annual in-service review schedule. 


\section{Barriers and Facilitators}

As previously mentioned, Kotter's fifth step included eliminating obstacles that get in the way of progress. To the extent possible, barriers were anticipated and managed proactively. Some of the many potential barriers included staffing challenges that could have impeded training attendance, staff turnover, access to supplies, a lack of buy-in, lack of staff confidence, lack of facility policies and procedures as well as the potential for noncompliance with protocols. The value of written policies and procedures was discussed with the ED director, and an offer was made to initiate the development of written policies and procedures. The ED director elected to postpone policy development. Multiple educational training sessions were provided to address scheduling barriers that may have prevented staff from attending education sessions. Staff members were involved in identifying and discussing possible barriers and in offering potential solutions to those barriers. Project facilitators included encouraging and supporting project champions. Also, facility support and flexibility in scheduling and presenting educational training sessions helped to facilitate increased staff participation.

\section{Project Schedule}

A critical factor in developing the project schedule was the requirement for obtaining approval from the Internal Review Board (IRB) before implementing the project. Project completion was planned for 15 weeks, and the timeline included an allowance for adjustments if necessary. Initial steps for the first two weeks included preparation and submission of the proposal to the IRB, development of the interprofessional project team, establishment and communication of the project vision, identification of risks, and barriers. During the third and fourth weeks, education handouts were prepared and approved for Continuing Education (CE) from the Board of Nursing (BON) was obtained. Baseline data was collected, and educational 
training began during week five. Education with pre- and post-testing was planned for weeks five through nine with two additional weeks allocated for remedial training, mentor training, or timeline adjustments. Practice audits with feedback were scheduled for week five through the project completion. Data collection, analysis, and comparison were planned for weeks eight, twelve, and fifteen. The project schedule includes key deliverable due dates and can be found in Appendix D.

\section{Resources}

Project resources included interprofessional team members who provided critical support for various areas of the project, as previously discussed in Kotter's second step. Also, a SANE trained ED registered nurse provided SAFE practice expertise. Other resources for the project included the use of the training room, SAFE kits for skills training, and simulation mannequins. The facility had several available locations for conducting educational training, the SAFE kits for training were provided by Florida law enforcement and the regional SART at no charge. Also, simulation mannequins for skills training were provided at no cost to the facility.

\section{Budget}

The Florida Statutes section 960.28 (2019) explains state regulations regarding SA victim assistance with reimbursement from the Crime Victims' Services Office for sexual assault forensic examinations and fortunately, in 2019 Florida increased the maximum reimbursement rate from $\$ 500.00$ to $\$ 1000.00$. After factoring a $\$ 1,000.00$ rate with an estimate of five cases, the total revenue would be $\$ 5,000.00$. It was impossible to predict the number of SA patients who may be examined and treated in the ED during this project; therefore, an estimate of five SA patients was used for purposes of budget calculations. Fortunately, no individuals presented to the ED for examination during the project evaluation period. Expert witness reimbursement 
could provide additional revenue; however, that did not occur during the duration of the project. The facility budgeted two hours for education for 25 staff members at an estimated cost of $\$ 30.00$ per hour for a total of $\$ 1050.00$ in salary expenses. Because Florida regulations require educational training on the subject of SAFE for ED staff, the costs were allocated to the organizations existing education budget (Treatment of Sexual Assault Patients, Florida Statutes $\S 395.1021,2019)$. Some cost savings were incurred when on duty staff were able to attend training with supervisory staff providing patient care coverage to minimize the use of education budget funds. The estimated cost for minimal office supplies was $\$ 20.00$. Indirect facility expenses for electricity, water, phone, internet, office supplies, security services, and cleaning services were estimated at a total of $\$ 50.00$. Disposable supplies included gloves, gowns, speculums, specimen cups, pregnancy tests, STI tests, patient drapes, patient gowns, paper bags, swabs measuring devices, and labels. Medications included antibiotics, HIV prophylaxis, antinausea medication, and ovulation prevention medication. The use of supplies varies depending on the nature of the SA and patient choices. Estimates for disposable expenses and drugs were $\$ 20.00$ per patient for a total of $\$ 100.00$. Existing items included an examination table, a digital camera, an alternative light source (ALS), and a specimen refrigerator. Florida Law Enforcement provided SA examination kits at no charge. The director reported that no SA patients presented to the ED for examination during the project implementation and evaluation timeframe; therefore, no costs were incurred for SA patient examinations. The financial information was documented in a budget table (See Table 1).

\section{Project Management Role and Leadership Skills}

Preparation for the project manager role began with the identification of the skills that would be necessary for the project through a review of the book "Project management for the 
unofficial project manager” (Kogon et al., 2015). Preceptor input provided expertise and guidance in determining efficient and effective strategies for managing and completing the project. The ability to differentiate between efficient management of things, including deadlines or deliverables and effective leadership for people, was noted by Aston (2019) and was practiced in this project to keep the team motivated while maintaining the project within budget and on schedule. Critical skills for this project included communicating, planning, negotiating, managing risks, and managing time, as well as having expertise in the subject matter. Also, interprofessional collaborative skills were vital for securing management support and staff buyin. To manage the education and training components of this project, expertise on the topic of performing SAFEs was necessary. My expertise was increased by completing the IAFN 40-hour SANE Adult and Adolescent educational program as well as the 43-hour IAFN SANE Pediatric education program for a total of 83 hours of specialized education, which led to the achievement of the IAFN SANE-A certification credentials. Additional preparations included completion of over 300 hours of on-call time and practicum experience, with over 50 case simulations and 30 live speculum examinations.

\section{Project Evaluation}

Kotter's 8-step change theory was used as the framework for evaluating the project plans, process, and results. Participant selection included licensed ED staff who provide care for SA patients. The project results were evaluated by comparing baseline data to post-implementation data about the number of knowledgeable and available ED staff for performing SAFEs and the wait time for SA victims between ED registration and initiation of the SAFE. No patients were recruited or included in the project, and no patient data was collected. The participant description includes hospital staff members who provide clinical care for ED patients. Participants were 
recruited by the ED director. Florida State regulations require initial and ongoing training for ED staff on the provision of care for SA patients in the ED setting, which provides strong support for project completion in this ED setting.

As the project manager, I was responsible for several activities that included collecting, storing, protecting, and analyzing data as well as maintaining the integrity of the process. Primary data on the number of available and knowledgeable ED staff for performing SAFEs was collected after the Internal Review Board (IRB) approval, before implementation, during implementation, and upon completion of the project. I collected data about the number of available and knowledgeable staff from the educational training sessions and the ED director. Additional baseline data were collected from hospital reports on the ED wait times.

Hard copy data was stored in a locked desk drawer in a locked office. Electronic data was stored in an excel file on a laptop with strong password protection and in a locked desk drawer in a locked office when not in direct use. No personal protected patient information or any personally identifiable staff information was collected or stored. The integrity of the data sources was maintained with an internal facility database that is preserved through strict IT security. The integrity of the ED wait time records for initiation of the SAFEs are maintained by the ED director, and files do not contain any identifiable patient or staff data. Evaluation of the data indicated no missing data upon completion of project implementation. Data will continue to be stored in a locked desk drawer and password protected excel document. Upon completion of the DNP degree, data will be destroyed beyond reclamation.

The data evaluation design involved comparing baseline data to post-intervention data, which demonstrated that implementation of SAFE protocols through staff education and training 
was effective for increasing the number of available and knowledgeable staff for performing SAFE care in the ED and reducing ED wait time for SAFE initiation.

Outcome benchmarks included increasing the number of available and knowledgeable ED staff for performing SAFEs to at least $80 \%$ of existing ED staff. Another outcome benchmark was to reduce ED wait time for SA patients to 30 minutes or less from registration to initiation of the SAFE. Process measures included tracking project deliverables to manage and maintain the project status in line with the established benchmarks and within the timeline. Routine formative evaluations included measures to ensure the project did not disrupt adequate ED staffing. Balancing measures involved collaborations with the ED director and clinical coordinator to ensure required ED staffing levels were maintained during education and training sessions. The balancing benchmarks included scheduling no more than five staff members at any time to attend each educational training session.

Financial measures included a weekly review of the project's financial status to ensure compliance within the budget. Financial benchmarks were limited to no more than two hours of educational training time per staff member. The project budget was managed through the routine tracking of all finances.

Sustainability measures included strategies to maintain the use of Florida protocols for SA examinations and forensic evidence collection by embedding protocols into new hire orientation and incorporating annual education review schedules. A skills checklist was provided, and annual skills checks for SAFE competencies were planned. Also, written material was provided for staff resources in the ED. 


\section{Project Evaluation Results}

The evaluation process serves several purposes, including monitoring project success and identifying problems (Harvey \& Wensing, 2003). Kotter's change model, in conjunction with the PDSA model, guided the project evaluation. The project evaluation plan identified that the implementation of SAFE protocols with educational training increased the number of available and knowledgeable ED staff for completing SAFEs to over $80 \%$. Fortunately, after the Florida protocols were implemented, no individuals presented to the ED, indicating that they had been sexually assaulted. However, it is expected that the ED wait times between patient registration and SA exam initiation will decrease to 30 minutes or less after the project increased the number of knowledgeable ED staff for performing SAFE's to over $80 \%$ of available ED staff.

Preliminary planning and project management effectively controlled the potential for extraneous variables. Close monitoring and management ensured that the independent variable of implementing Florida protocols directly produced the intended changes in the dependent variable of increased numbers of staff who are knowledgeable for performing SA examinations. Multiple evaluation strategies were incorporated, including formative, summative, and process evaluations, which will be discussed in the following sections.

\section{Formative Evaluation}

Formative evaluations were completed weekly during project implementation to ensure the project progressed as scheduled and determine if any changes were needed to improve the project. Results were noted on a run chart to track the number of ED staff who completed education and training on SAFE protocols. According to DeAnda (2018), the PDSA cycles are useful for identifying opportunities to improve the project before initiating the next cycle. During the formative evaluation, balancing measures were employed to ensure that the scheduling of ED 
personnel for educational training sessions did not have a negative impact on efficient staffing in the ED for the provision of emergency services. This included consulting with the ED director and clinical coordinator to verify adequate staffing coverage during educational training sessions. The use of a valid pre, and post-test and a skills-check list were useful for measuring SAFE competency.

The "Sexual Assault Forensic Examination Pre/Post-test” (Fitzpatrick et al., 2012) was used, with permission from the publisher, for evaluating the ED staff knowledge levels about SA patient care, and each test took approximately 5 minutes to complete. The 20-question SAFE pre-test and the forensic examination simulation checklist were developed by Fitzpatrick et al., (2012) with the IAFN education guidelines as well as the national and state SAFE protocols (IAFN, 2018; US Department of Justice, 2013; Florida Office of the Attorney General, 2015). Test validity was confirmed by identifying and comparing the test with vital elements of the SAFE and educational criteria derived from the previously mentioned resources (Fitzpatrick et al., 2012). The process for establishing content validity included administering a draft of the pre and post-test to two trained nurses who provided feedback. Next, the test was administered to two nurses who had completed SANE training, and they were able to score $100 \%$ on the test (Fitzpatrick et al., 2012). The cut point for measuring results was $80 \%$ accuracy. The pre-post intervention knowledge test can be seen in Appendix E, and the forensic examination simulation checklist can be reviewed in Appendix F. The examination simulation checklist was used in conjunction with skills simulation demonstrations and competency verifications.

The US Department of Justice, (2018), national training standards for SA forensic examiners provides an educational training outline that was used to ensure the educational training content was presented consistently (see Appendix G). The Florida Department of Law 
Enforcement (FDLE) Indian River crime laboratory sexual assault evidence kit includes a guideline checklist that can be used to note and evaluate the wait time between ED registration and initiation of the SAFE (see Appendix H). The SAFE kit checklist includes no patient information, which helps to ensure the strict protection of human rights and privacy. Project timeline monitoring included weekly evaluations to ensure timely completion of key deliverables and identification of any necessary changes. In keeping with the PDSA model, the results of formative evaluations were used to inform and improve the project while maintaining the project plan. For example, monitoring how many ED staff members completed the educational training program ensured that at least $80 \%$ of ED staff had completed training sessions. Maintaining an attendance $\log$ for educational training completion established compliance with state regulations that require the provision of care for SA patients and education of ED staff (Treatment of SA Patients, Florida Statutes $§ 395.1021,2019)$. Furthermore, the evaluations helped determine when individual remedial training or additional group training sessions where needed while maintaining the timeline.

\section{Summative Evaluations}

Even though data was collected throughout the project, the summative evaluations were completed within one week of project completion for the determination of outcome measures. The pre- and post-intervention data variables were collected, compared, and analyzed for summative evaluations using a quantitative data analysis method. The summative evaluations demonstrated the intervention of implementing SAFE protocols substantially increased the number of available and knowledgeable ED staff for performing timely SAFEs. Summative evaluations also identified results, findings, intervention impacts, and future implications 
reflective of the "act" phase of the PDSA model. A participant sign-in record was used to collect primary data on the number of ED staff who completed educational training on SAFE protocols.

The ED time reports were planned for comparison of ED wait times before and after the project intervention with the goal of reducing the ED wait time by the 15 th week of the project to 30 minutes or less between ED registration and initiation of the SAFE examination. Du Mont et al., (2018) reported that ED wait time reductions were previously demonstrated in a similar study. The baseline average ED wait times were collected from the Hospital Compare website data for the prior year of 2018 (CMS, n.d.). Post-implementation data could not be compared to baseline data because no SA patents arrived at the ED for evaluation during the evaluation phase.

\section{Participant Selection and Methodology}

The education and training sessions on Florida state protocols for sexual assault forensic examinations were available for all ED staff who are involved in providing care for SA patients. Multiple educational training session dates and times were posted in the ED for several weeks to encourage attendance and participation. The ED director-approved two hours of educational training time for each ED nurse, and the hospital provided support for the project, including protocol implementation through educational training. On the other hand, in light of the violent and emotionally charged nature of SAs, no patients were included, nor was any personally identifiable information collected.

\section{Variables}

An independent variable in this project was the implementation of Florida SAFE protocols, which had a positive impact on the dependent variables. Two dependent variables included the number of available and knowledgeable ED staff and the timely initiation of SAFEs. The project outcome evaluation results determined that the intervention was effective. 


\section{Data Analysis}

The IBM SPSS program analysis included a comparison of baseline and post-intervention data. An Excel data collection tool was used to note pre- and post-intervention data for comparison and statistical analysis testing. Data were entered into the IBM SPSS system and checked for accuracy before calculating results using a standard 0.5 p-value. Primary data were collected before and during the project to track the number of available and knowledgeable ED staff for performing SA examinations and forensic evidence collection. Primary data were collected on the number of ED staff who completed the educational training by using an attendance roster for staff to sign in for training sessions. Paired $t$-tests compared baseline with post-implementation data, and the results demonstrated that $83.3 \%$ of staff completed educational training and scored over $90 \%$ on the post-test. It is expected that the increased number of knowledgeable staff for performing SA examinations will decrease the wait time for individuals who present to the ED, indicating that they have been sexually assaulted. This expectation is based upon previous studies where the implementation of protocols with staff education and training led to an increase in available and knowledgeable staff for performing SAFES and a decrease in ED wait times for sexual assault patients (Dumont et al. 2018). These results are clinically significant and meaningful to achieving timely, consistent, and high-quality care for individuals who present to the ED, indicating that they have been sexually assaulted. The results are also considered statistically significant because the p-value was identified in the SPSS testing as below 0.05 . Results confirmed that implementing protocols increase the number of available staff who are knowledgeable to perform SA examinations, as is supported in the evidence-based literature findings. The project results are depicted in Table 2. 


\section{Protection of Human Rights and Privacy}

The project included ongoing monitoring for ethical considerations such as protecting human rights and ensuring privacy throughout the project. The project proposal was submitted to the university IRB and subsequently submitted to the facility where it was reviewed and approved. The literature supported that the proposed intervention is a known evidence-based practice and posed no more than a mild risk. The ethical practice was reviewed with project members to maximize compliance. Also, to maintain privacy, no, patient data was collected.

\section{Discussion and Implications}

The primary outcome finding from this quality improvement practice change project was that implementing protocols for performing SAFEs is effective in increasing the number of available staff who are knowledgeable for performing these examinations. The project outcome is comparable to outcomes identified in the literature that demonstrated increased staff knowledge, skills, and confidence in performing SA examinations after implementation of protocols with educational training (Dumont et al., 2018). The outcome resulted in an increase to $83.3 \%$ of ED nurses being knowledgeable for performing SA exams. The increased number of available and knowledgeable staff is clinically meaningful as it enables the facility to provide timely, effective, and consistent care for sexual assault patients as well as effective forensic evidence collection and productive legal testimony if needed. The practice change was implemented as planned with consistent use of established protocols and educational training materials. The process measure of ensuring that adequate levels of staffing were maintained in the ED setting during educational training sessions was a crucial component to implementation because staff who attended training needed to be able to focus on educational content without distractions. The ability to participate in training while off the work schedule, or with an 
assigned nurse to cover ED responsibilities, made it possible for staff to learn and develop critical skills.

Limitations of the project included a restricted budget for staff education and training, as well as the finite number of ED staff that could be scheduled for training. Not all ED staff could attend the training at one time so that adequate staffing levels were maintained. Limiting the number of ED staff at each session served as a balancing measure to ensure sufficient and appropriate ED staffing levels were maintained in the ED during education sessions, which resulted in the need for scheduling multiple sessions. These conditions limited the project to two hours of educational and skills training. Implications of process measures include acknowledgment of interprofessional collaborations between staff members who worked in the ED during educational training sessions to make it possible for other staff to attend educational training, which helped to minimize project costs. Suggestions for next steps include embedding the practice change into new ED employee orientation and annual training programs. Implications include a recommendation for further quality improvement research that may be beneficial to determine effective content for ongoing education on the topic of SA examination, forensic evidence collection, and court testimony for ED staff. The take-home message from this project is that utilization of available resources with close management can facilitate the implementation of protocols that enhance staff knowledge and skills for performing SAFE's and improving the quality of care for SA patients.

\section{Dissemination}

Project closure included a review and evaluation of the strengths, weaknesses, as well as any opportunities for improvements before disseminating the results. This process included feedback from the project preceptor, course instructor, and university peers. The results included 
baseline and outcome findings with a basic run chart to track the project progress. Initially, project results and goal achievement were presented during a meeting with the ED director and clinical care coordinator.

Subsequent dissemination will involve sharing project results internally with management staff for Quality Improvement (QI) reporting, including the CNO, ED director, and other interested department directors. The plan for external dissemination includes sharing project results with the regional SART during a committee meeting. The SART team was chosen because its members provide local resources and networking for the practicum site. Additional dissemination plans include a presentation during a Florida Chapter of the IAFN webmeeting. The Florida Chapter of the IAFN was selected for dissemination because group members represent forensic nursing personnel throughout Florida. A target journal for project dissemination is the Journal of Forensic Nursing because of its strong focus on the subject matter and the primary audience of forensic nurses who specialize in the care of SA patients. As a requirement of the DNP program, this paper will be submitted in full text to the institutional repository called SOAR@USA, which will improve the discoverability and availability of the DNP project. A final dissemination approach will be submission to The Virginia Henderson Global Nursing e-Repository, which will allow worldwide sharing of this project information.

\section{Conclusion}

Sexual assault patients often depend on EDs for examination and treatment. Care for SA patients includes a unique combination of clinical and forensic knowledge as well as unique skills for completing the SAFE (DuMont et al., 2018). When knowledgeable ED staff are not available to perform the SAFE, the wait time may be delayed, and SA patients may leave the facility before receiving the necessary examination and treatment. When untrained staff performs 
the SAFE, they may omit or incorrectly perform vital clinical or forensic components. Results of untimely or incorrectly performed SAFEs include suboptimal treatment and inadmissible or missing forensic evidence. Literature supports that implementing SAFE protocols is an effective strategy for increasing the number of available and knowledgeable ED staff for performing timely and consistent SAFEs. The project results similarly demonstrated that implementing SAFE protocols is useful for increasing the number of available and knowledgeable staff for performing SAFE's and for reducing the wait time for initiating SAFE's in the ED. 


\section{References}

Adams, P. \& Hulton, L. (2016). The sexual assault nurse examiner's interactions within the sexual assault response team. Advanced Emergency Nursing Journal, 38 (3), 213-227. doi: 10.1097/TME.0000000000000112

Agency for Healthcare Research \& Quality. (2013). Plan-Do-Study-Act (PDSA) Cycle.

Retrieved from https://innovations.ahrq.gov/qualitytools/plan-do-study-act-pdsa-cycle

Aston, B. (2019). 7 Essential Project Management Skills for 2019. Retrieved from https://thedigitalprojectmanager.com/project-management-skills/

Auten, J. D., Ross, E. M., French, M. A., Li, I. Z., Robinson, L., Brown, N., .. Tanen, D. A. (2015). Low-Fidelity Hybrid Sexual Assault Simulation Training's Effect on the Comfort and Competency of Resident Physicians. Journal of Emergency Medicine, 48(3), 344350. https://doi.org/10.1016/j.jemermed.2014.09.032

Baloh, J., Zhu, X., \& Ward, M. M. (2018). Implementing team huddles in small rural hospitals: How does the Kotter model of change apply? Journal of Nursing Management, 26(5), 571-578. https://doi.org/10.1111/jonm.12584

Blumling, A., Kameg, K., Cline, t., Szpak, J., \& Koller, C. (2018). Evaluation of a Standardized Patient /Simulation on Undergraduate Nursing Students' Knowledge and Confidence About Intimate Partner Violence. Journal of Forensic Nursing, 14, 174-179. doi:

\subsection{7/JFN.0000000000000212}

Bush, K. (2017). Adult and adolescent sexual assault patients in the emergency care setting. Retrieved from https://www.ena.org/docs/default-source/resource-library/practiceresources/position-statements/jointstatements/adultandadolescentsexualassaultpatientser.pdf?sfvrsn=234258f1_6 
Campbell, R., Townsend, S. M., Shaw, J., Karim, N., \& Markowitz, J. (2015). Can a workbook work? Examining whether a practitioner evaluation toolkit can promote instrumental use. Evaluation and Program Planning, 52, 107-117. Retrieved from https://0b30df6sbmp02-y-https-www-sciencedirect-com.prxusa.lirn.net/science/article/pii/S0149718915000506

Christenson, D., \& Walker, D. H. T. (2004). Understanding the role of "vision" in project success. Project Management Journal, 35(3), 39-52. https://doi.org/10.1177/875697280403500306

Cochran, C. B. (2019). An evidence-based approach to suicide risk assessment after sexual assault. Journal of forensic nursing, 15(2), 84-92. doi: 10.1097/JFN.0000000000000241

DeAnda, R. (2018). Stop the bottleneck: Improving patient throughput in the emergency department. Journal of Emergency Nursing, 44(6), 582-588. https://doi.org/10.1016/j.jen.2018.05.002

Dearholt, S.L., \& Dang, D. (2012). Johns Hopkins Nursing Evidence-Based Practice Model and Guidelines (2nd ed.). Indianapolis, Indiana: Sigma Theta Tau International.

Donahue, S., Schwien, M., \& LaVallee, D. (2019). Educating the Emergency Department Staff on the Identification and Treatment of Human Trafficking Patients. JEN: Journal of Emergency Nursing, 45(1), 16-23. https://doi.org/10.1016/j.jen.2018.03.021

Du Mont, J., Macdonald S., White, M. Turner, L., White, D., Kaplan, S., \& Smith, T. (2014). Client Satisfaction with Nursing-led Sexual Assault and Domestic Violence Services in Ontario. Journal of Forensic Nursing, 10, 122-134. doi: 10.1097/JFN.0000000000000035 
Du Mont, J., Solomon, S., Kosa, S., \& Macdonald, S. (2018). Development and evaluation of sexual assault training for emergency department staff in Ontario, Canada. Nurse Education Today, 70, 124-129. doi.org/10.1016/j.nedt.2018.08.025

Egyud, A., Stephens, K., Swanson-Bierman, B., DiCuccio, M., \& Whiteman, K. (2017). Implementation of human trafficking education and treatment algorithm in the emergency department. Journal of Emergency Nursing, 43(6), 526-531. doi.org/10.1016/j.jen.2017.01.008

Emergency Nurses Association. (2019). Position Statements. Retrieved from https://www.ena.org/practice-resources/resource-library/position-statements/-incategory/categories/ena/resources/practice-resources/position-statement/joint-positionstatements

Fitzpatrick, M., Ta, A., Lenchus, J., Arheart, K. L., Rosen, L. F., \& Birnbach, D. J. (2012). Sexual assault forensic examiners training and assessment using simulation technology [PDF]. Journal of Emergency Nursing, 38(1), 85-90. Retrieved from http://anesthesiology.med.miami.edu/documents/patientsafety/Sexual_Assault_Forensic_Examiners_Training.pdf

Fla. Stat. 960.28 (2019). Payment for victims’ initial forensic physical examinations. http://www.flsenate.gov/Laws/Statutes/2019/960.28

Florida Office of the Attorney General. (2015). Adult and child sexual assault protocols [PDF]. Retrieved from https://myfloridalegal.com/webfiles.nsf/WF/JFAO77TKCT/\$file/ACSP.pdf

The Florida Senate. (2018). https://www.flsenate.gov/laws/statutes/2019/395.1021 
Gilles, C., Manigart, Y., Rousseau, C., Libois, A., Gennotte, A. F., \& Rozenberg, S. (2019). Implementation of a protocol and staff educational sessions improves the care of survivors of sexual assault. Maturitas, 124, 39-42. doi.org/10.1016/j.maturitas.2019.03.004

Greenbaum, V. J., Livings, M. S., Lai, B. S., Edinburgh, L., Baikie, P., Grant, S. R., ... SelfBrown, S. (2018). Evaluation of a tool to identify child sex trafficking patients in multiple healthcare settings. Journal of Adolescent Health, 63(6), 745-752. https://doi.org/10.1016/j.jadohealth.2018.06.032

Greenbaum, V. J., Titchen, K., Walker-Descartes, I., Feifer, A., Rood, C. J., \& Fong, H. (2018). Multi-level prevention of human trafficking: The role of health care professionals. Preventive Medicine, 114, 164-167. https://doi.org/10.1016/j.ypmed.2018.07.006 Harvey, G., \& Wensing, M. (2003). Methods for evaluation of small-scale quality improvement projects. Quality \& safety in health care, 12(3), 210-214. doi:10.1136/qhc.12.3.210

Hemmings, S., Jakobowitz, S., Abas, M., Bick, D., Howard, L. M., Stanley, N., . . Oram, S. (2016). Responding to the health needs of survivors of human trafficking: A systematic review. BMC Health Services Research, 16, 1-9. doi.org/10.1186/s12913-016-1538-8 International Association of Forensic Nurses. (2018). Forensic Nursing Education Guidelines. Retrieved from https://www.forensicnurses.org/page/EducationGuidelines

Jina, R., Jewkes, R., Christofides, N., \& Loots, L. (2014). A cross-sectional study on the effect of post-rape training on knowledge and confidence of health professionals in South Africa. International Journal of Gynecology and Obstetrics, 126(2), 187-192. https://doi.org/10.1016/j.ijgo.2014.02.011 
Jordan, K. S., Steelman, S. H., Leary, M., Varela-Gonzalez, L., Lassiter, S. L., Montminy, L., \& Bellow, E. F. (2019). Pediatric sexual abuse: An interprofessional approach to optimizing emergency care. Journal of forensic nursing, 15(1), 18-25. doi:10.1097/JFN.0000000000000232

Joshi, M., Ransom, E., Nash, D. B., \& Ransom, S. B. (2008). The healthcare quality book: Vision, strategy, and tools. Chicago, IL: Health Administration Press.

Kogon, K., Blakemore, S., \& Wood, J. (2015). Project Management for the Unofficial Project Manager (D. Harmsen Ed.) Dallas, Tx.: BenBella Books, Inc.

Lawson, T., Weekes, L., \& Hill, M. (2018). Ensuring Success and Sustainability of a Quality Improvement Project. BJA Education, 18(5), 147-152. https://doi.org/10.1016/j.bjae.2018.02.002

Lock, D. (2018). Kotter's 8 Step Change Model. Retrieved from https://daniellock.com/kotters-8step-change-model/

Maclean, D. F. W., \& Vannet, N. (2016). Improving trauma imaging in Wales through Kotter's theory of change. Clinical Radiology, 71(5), 427-431. https://doi.org/10.1016/j.crad.2016.02.003

Marchetti, C. A., Fantasia, H. C., \& Molchan, L. (2014). Attitudes of Adult/Adolescent Sexual Assault Nurse Examiners and Caring for Younger Patients. Journal of Emergency Nursing, 40(1), 39-45. https://doi.org/10.1016/j.jen.2012.09.002

Marks, S. A., Kaiser, L., \& McCleery, M. B. (2017). A Novel Approach to Sexual Assault Nurse Examiner Training: A Pilot Program. Clinical Simulation in Nursing, 13(12), 595-600. doi.org/10.1016/j.ecns.2017.07.002 
Morse, J. (2019). Legal mobilization in medicine: Nurses, rape kits, and the emergence of forensic nursing in the United States since the 1970s. Social Science \& Medicine, 222, 323-334. https://doi.org/10.1016/j.socscimed.2018.12.032

National Institute of Justice. (2017). National Best Practices for Sexual Assault Kits: A Multidisciplinary Approach. Retrieved from https://www.nij.gov/topics/lawenforcement/investigations/sexual-assault/Pages/national-best-practices-for-sexualassault-kits.aspx

Nielson, M. H., Strong, L. \& Stewart, J. G. (2015). Does Sexual Assault Nurse Examiner (SANE) Training Affect Attitudes of ED Nurses Toward Sexual Assault Survivors?. Journal of Forensic Nursing, 11 (3), 137-143. doi: 10.1097/JFN.000000000000008

Patterson, D., Resko, S. (2015). Is online Learning a Viable Training Option for Teaching Sexual Assault Forensic Examiners? Journal of Forensic Nursing, 11, 181-189. doi: 10.1097/JFN.0000000000000084

Peterson, C., DeGue, S., Florence, C., \& Lokey, C. N. (2017). Lifetime Economic Burden of Rape Among US Adults. American journal of preventive medicine, 52(6), 691-701. doi: 10.1016/j.amepre.2016.11.014.

Pollack, J., \& Pollack, R. (2015). Using Kotter's Eight Stage Process to Manage an Organizational Change Program: Presentation and Practice. Systemic Practice \& Action Research, 28(1), 51-66. https://doi.org/10.1007/s11213-014-9317-0

Rape, Abuse \& Incest National Network About Sexual Assault. (2019). About Sexual Assault. Retrieved from https://www.rainn.org/about-sexual-assault 
Raunick, C. B., Lindell, D., Morris, D. L., \& Backman, T. (2015). Vicarious Trauma Among Sexual Assault Nurse Examiners. Journal of Forensic Nursing, 11(3), 123. doi: 10.1097/JFN.0000000000000085

Rogers, A., McIntyre, S. L., Rossman, L., Solis, S., Bacon-Baguley, T., \& Jones, J. (2019). The forensic rape examination: Is colposcopy essential? The American Journal of Emergency Medicine, 37(5), 999-1000. http://dx.doi.org/10.1016/j.ajem.2018.10.015

Scannell, M., Lewis-O’Connor, A., \& Barash, A. (2015). Sexual Assault Simulation Course for Healthcare Providers: Enhancing Sexual Assault Education Using Simulation. Journal of Forensic Nursing, 11(4), 190. Retrieved from https://journals.lww.com/forensicnursing/Fulltext/2015/10000/Sexual_Assault_Simulatio n_Course_for_Healthcare.5.aspx

Scannell, M., MacDonald, A. E., Berger, A., \& Boyer, N. (2018). The Priority of Administering HIV Postexposure Prophylaxis in Cases of Sexual Assault in an Emergency Department. Journal of Emergency Nursing, 44(2), 117-122. Retrieved from https://www.sciencedirect.com/science/article/abs/pii/S0099176716303270

Tanner, R., \& Tanner, R. (2019). Leading Change (Step 7) - Consolidate Gains and Implement More Change. Retrieved from https://managementisajourney.com/leading-change-step-7consolidate-gains-and-implement-more-change/

Tennessee, A. M., White, B. M., Simpson, K. N., \& Bradham, T. S. (2017). The Monetary Cost of Sexual Assault to Privately Insured US Women in 2013. The American Journal of Public Health, 107(6), 983-988. https://doi.org/10.2105/AJPH.2017.303742 
Tozzo, P., Ponzano, E., Spigarolo, G., Nespeca, P., \& Caenazzo, L. (2018). Collecting sexual assault history and forensic evidence from adult women in the emergency department: a retrospective study. BMC health services research, 18(1), 383. doi:10.1186/s12913-018$3205-8$

Treatment of Sexual Assault Patients, FL Stat. §395.1021 (2019). Retrieved from https://m.flsenate.gov/Statutes/395.1021

U.S. Centers for Medicare \& Medicaid Service (n.d.). Hospital Compare Quality of Care Profile Page. Retrieved from https://data.medicare.gov/data/archives/hospital-compare

U.S. Department of Justice. (2013). A national protocol for sexual assault medical forensic examinations $[\mathrm{PDF}]$. Retrieved from https://cdn.ymaws.com/www.safeta.org/resource/resmgr/Protocol_documents/SAFE_PR OTOCOL_2012-508.pdf

U.S. Department of Justice. (2018). National Training Standards for Sexual Assault Medical Forensic Examiners. Retrieved from https://www.justice.gov/ovw/page/file/1090006/download

Valentine, J. L. (2018). Forensic nursing: Overview of a growing profession. American Nurse Today, 13(12), 42-44. Retrieved from https://www.americannursetoday.com/forensic-nursing-overview-of-a-growing-

Whalen, M., Hansoti, B., Hsieh, Y.-H., Saheed, M., Signer, D., \& Rothman, R. (2018). Translation of Public Health Theory into Nursing Practice: Optimization of a NurseDriven HIV Testing Program in the Emergency Department. Journal of Emergency Nursing, 44(5), 446-452. https://doi.org/10.1016/j.jen.2018.02.002profession/ 
White, K. M., Dudley-Brown, S., \& Terhaar, M. F. (Eds.). (2016). Translation of evidence into nursing and health care. New York, NY: Springer Publishing Company.

Witt, J. S., Carlson, K., Colbert, S., Cordle, C., Hitchcock, K., \& Kelly, P. J. (2015). SANE-APALOOZA: A Clinical immersion experience to close the gap for new sexual assault nurse examiners. Journal of Forensic Nursing, 11(2), 101-106. doi.org/10.1097/JFN.0000000000000069

Yildiz, T., Selimen, D., \& Dogan, D. (2014). A Study Comparing the Pre- and Post-Training Knowledge of Emergency Department Nurses in Turkey for the Diagnosis of Physically Abused Women. Journal of Family Violence, 29(5), 519-525. https://doi.org/10.1007/s10896-014-9608-3 
Table 1

Project Budget

\section{EXPENSES}

Direct

Salary and benefits: education (educational training)

Supplies: (\$20.00 per patient)

Services

Statistician

Indirect :

Office expenses: paper, copies, certificates

Overhead

Estimate $\$ 10.00$ per patient

(Par level of 10 patients)

Total Expenses

Net Balance

\section{REVENUE}

Billing

$(\$ 1,000.00$ per patient $\times 5)$

$\$ 5000.00$

$\$ 100.00$ Grants

Institutional budget support
$\$ 20.00$

$\$ 50.00$

$\$ 1720.00$ Total Revenue

$\$ 5,000.00$

$\$ 3280.00$ 
Table 2

Available staff who are knowledgeable for performing sexual assault examinations and forensic evidence collection.

\begin{tabular}{lllll}
\hline & Mean & Number & Sig. & Standard Deviation \\
\hline Baseline & .03 & 1 & .000 & .183 \\
Post-Intervention & .83 & 25 & .023 & .379 \\
\hline
\end{tabular}

Note: Project Results IBM SPSS Paired Sample T-Test 


\section{Appendix A}

\section{Summary of Primary Research Evidence}

\begin{tabular}{|c|c|c|c|c|c|c|}
\hline Citation & Sample Size & $\begin{array}{l}\text { Design, Level, } \\
\text { \& Quality Grade }\end{array}$ & $\begin{array}{c}\text { Intervention \& } \\
\text { Comparison } \\
\text { Definitions }\end{array}$ & $\begin{array}{l}\text { Theoretical } \\
\text { Foundation }\end{array}$ & $\begin{array}{l}\text { Outcome } \\
\text { Definition }\end{array}$ & $\begin{array}{l}\text { Results - Key } \\
\text { Findings }\end{array}$ \\
\hline $\begin{array}{l}\text { Auten, J. D., Ross, E. M., French, M. A., Li, I. Z., Robinson, } \\
\text { L., Brown, N., ... Tanen, D. A. (2015). Low- } \\
\text { Fidelity Hybrid Sexual Assault Simulation } \\
\text { Training's Effect on the Comfort and Competency } \\
\text { of Resident Physicians. Journal of Emergency } \\
\text { Medicine, 48(3), 344-350. } \\
\text { https://doi.org/10.1016/j.jemermed.2014.09.032 }\end{array}$ & 12 ED staff & $\begin{array}{l}\text { Quality } \\
\text { improvement study } \\
\text { designed to align } \\
\text { with outcome } \\
\text { measures from a } \\
\text { sentinel study, } \\
\text { including written } \\
\text { knowledge testing, } \\
\text { simulation } \\
\text { scenarios, and } \\
\text { questionnaires. } \\
\text { The study was } \\
\text { approved by IRB. } \\
\text { VB }\end{array}$ & $\begin{array}{l}\text { The intervention } \\
\text { included an 8-hour } \\
\text { training course } \\
\text { based on a } \\
\text { McLaughlin et al., } \\
\text { model with } \\
\text { lectures, scenarios } \\
\text { using simulation. } \\
\text { Post-training } \\
\text { debriefing was } \\
\text { completed, and } \\
\text { feed-bac was } \\
\text { provided. } \\
\text { A paired t-test was } \\
\text { used to compare } \\
\text { pre/post- } \\
\text { intervention } \\
\text { results. A } \\
\text { Wilcoxon signed- } \\
\text { rank test was used } \\
\text { to interpret } \\
\text { pre/post } \\
\text { competency and } \\
\text { comfort. }\end{array}$ & $\begin{array}{l}\text { The article did } \\
\text { not reflect a } \\
\text { theoretical } \\
\text { foundation; } \\
\text { however, Kolb's } \\
\text { experiential } \\
\text { learning cycle } \\
\text { may be } \\
\text { applicable as a } \\
\text { cycle of } \\
\text { technique, and } \\
\text { evaluations } \\
\text { were conducted } \\
\text { to determine } \\
\text { effectiveness. }\end{array}$ & $\begin{array}{l}\text { The outcome } \\
\text { includes the } \\
\text { impact of } \\
\text { simulation- } \\
\text { based } \\
\text { educational } \\
\text { training on the } \\
\text { ED staff's ability } \\
\text { to perform care } \\
\text { for sexual } \\
\text { assault patients. }\end{array}$ & $\begin{array}{l}\text { Results demonstrate } \\
\text { a } 13 \% \text { improvement } \\
\text { in pre/post written } \\
\text { test scoring and a } \\
44 \% \text { improvement } \\
\text { in action } \\
\text { completion. Staff } \\
\text { comfort/competency } \\
\text { scores increased } \\
\text { from } 2 \text { to } 4 \text { on a } \\
\text { Likert scale } \\
\text { evaluation. }\end{array}$ \\
\hline $\begin{array}{l}\text { Blumling, A., Kameg, K., Cline, t., Szpak, J., Koller., (2018), } \\
\text { Evaluation of a Standardized Patient /simulation } \\
\text { on Undergraduate Nursing Students' Knowledge } \\
\text { and Confidence About Intimate Partner Violence. } \\
\text { Journal of Forensic Nursing, 14, 174-179. doi: } \\
\text { 10.1097/JFN.0000000000000212 }\end{array}$ & $\begin{array}{l}64 \text { nursing } \\
\text { students }\end{array}$ & $\begin{array}{l}\text { Quality } \\
\text { improvement } \\
\text { VB }\end{array}$ & $\begin{array}{l}\text { Educational } \\
\text { training using } \\
\text { standardized } \\
\text { patient simulation } \\
\text { to increase } \\
\text { knowledge and } \\
\text { confidence. The } \\
\text { Physician } \\
\text { Readiness to } \\
\text { Manage IPV } \\
\text { Survey tool was } \\
\text { modified to } \\
\text { measure } \\
\text { confidence } 10 \text { item } \\
\text { pre/post-lecture }\end{array}$ & $\begin{array}{l}\text { No theoretical } \\
\text { framework is } \\
\text { documented. } \\
\text { The study } \\
\text { involved } \\
\text { improving } \\
\text { nurses' } \\
\text { expertise and } \\
\text { skills through } \\
\text { educational } \\
\text { training with } \\
\text { simulation. } \\
\text { Therefore, } \\
\text { Benner's theory } \\
\text { of novice to an }\end{array}$ & $\begin{array}{l}\text { Outcomes } \\
\text { include the } \\
\text { impact of } \\
\text { standardized } \\
\text { patient } \\
\text { simulation on } \\
\text { nursing } \\
\text { knowledge and } \\
\text { confidence in } \\
\text { the assessment } \\
\text { and intervention } \\
\text { of intimate } \\
\text { partner violence. }\end{array}$ & $\begin{array}{l}\text { Statistically } \\
\text { significant } \\
\text { improvement in } \\
\text { nurses' confidence } \\
\text { from } 14.04 \text { pre- } \\
\text { lecture to } 20.61 \text { was } \\
\text { achieved. }\end{array}$ \\
\hline
\end{tabular}




\begin{tabular}{|c|c|c|c|c|c|c|}
\hline & & & $\begin{array}{l}\text { and post- SP } \\
\text { simulation testing. }\end{array}$ & $\begin{array}{l}\text { expert may be } \\
\text { applicable. }\end{array}$ & & \\
\hline $\begin{array}{l}\text { Campbell, R., Townsend, S. M., Shaw, J., Karim, N., \& } \\
\text { Markowitz, J. (2015). Can workbook work? } \\
\text { Examining whether a practitioner evaluation } \\
\text { toolkit can promote productive use. Evaluation } \\
\text { and Program Planning, 52, 107-117. } \\
\text { https://doi.org/10.1016/j.evalprogplan.2015.04.005 }\end{array}$ & $\begin{array}{l}6 \text { Sexual assault } \\
\text { care programs. }\end{array}$ & $\begin{array}{l}\text { Quantitative and } \\
\text { qualitative data } \\
\text { collection. } \\
\text { Pre/post- } \\
\text { intervention } \\
\text { evaluations. } \\
\text { Quantitative data } \\
\text { analysis } \\
\text { VA }\end{array}$ & $\begin{array}{l}\text { Quantitative and } \\
\text { qualitative data } \\
\text { collection. } \\
\text { Pre/post- } \\
\text { intervention } \\
\text { evaluations. } \\
\text { Quantitative data } \\
\text { analysis was } \\
\text { completed with } \\
\text { simple descriptive } \\
\text { statistics for } \\
\text { percentages, } \\
\text { means, and } \\
\text { standard } \\
\text { deviations. For } \\
\text { 3qualitative data, } \\
\text { conventional } \\
\text { content analysis } \\
\text { was completed } \\
\text { with a compilation } \\
\text { of field notes and } \\
\text { transcripts. } 2 \\
\text { independent coders } \\
\text { independently } \\
\text { coded data. Codes } \\
\text { emerged from data } \\
\text { instead of priority } \\
\text { development. }\end{array}$ & $\begin{array}{l}\text { Preskill's model } \\
\text { of evaluation } \\
\text { capacity and } \\
\text { readiness was } \\
\text { documented. }\end{array}$ & $\begin{array}{l}\text { Outcomes } \\
\text { include the } \\
\text { identification of } \\
\text { education and } \\
\text { training needs, } \\
\text { application for } \\
\text { grants, } \\
\text { consistent care. }\end{array}$ & $\begin{array}{l}\text { Effectiveness } \\
\text { evaluation tools can } \\
\text { be used to identify } \\
\text { training and } \\
\text { education needs, } \\
\text { improve quality, } \\
\text { apply for grants, } \\
\text { and improve } \\
\text { outcomes. }\end{array}$ \\
\hline $\begin{array}{l}\text { Cochran, C., (2019) An Evidence-Based Approach to Suicide } \\
\text { Risk Assessment After Sexual Assault. Journal of } \\
\text { Forensic Nursing, 15, 84-92. doi: } \\
\text { 10.1097/JFN.0000000000000241 }\end{array}$ & $\begin{array}{l}51 \text { sexual assault } \\
\text { patients }\end{array}$ & $\begin{array}{l}\text { Quality } \\
\text { improvement } \\
\text { study. } \\
\text { VB }\end{array}$ & $\begin{array}{l}\text { Educational } \\
\text { training, } \\
\text { implementation of } \\
\text { an assessment tool, } \\
\text { and practice } \\
\text { guideline based on } \\
\text { international } \\
\text { practice guidelines. } \\
\text { The assessment } \\
\text { tool was validated } \\
\text { and deemed to } \\
\text { have high } \\
\text { reliability (.97) and } \\
\text { validity (r=0.40) in } \\
\text { prior research. A } \\
\text { power-point and } \\
\text { live presentation } \\
\text { were provided. A }\end{array}$ & $\begin{array}{l}\text { No theoretical } \\
\text { framework is } \\
\text { documented. } \\
\text { The process } \\
\text { used involved } \\
\text { improving nurse } \\
\text { expertise and } \\
\text { skills; therefore, } \\
\text { the Benner } \\
\text { theory of novice } \\
\text { to an expert may } \\
\text { be applicable. }\end{array}$ & $\begin{array}{l}\text { Outcomes } \\
\text { included staff } \\
\text { education, } \\
\text { implementation } \\
\text { of the suicide } \\
\text { risk assessment } \\
\text { tool, }\end{array}$ & $\begin{array}{l}\text { Compliance was } \\
\text { found to be } 100 \% \\
\text { for education } \\
\text { completion. The use } \\
\text { of the tool was } \\
\text { found to be high at } \\
98 \% \text { post- } \\
\text { intervention. } \\
\text { Adherence to IAFN } \\
\text { best practice was } \\
\text { increased. }\end{array}$ \\
\hline
\end{tabular}




\begin{tabular}{|c|c|c|c|c|c|c|}
\hline & & & $\begin{array}{l}\text { pre/post- } \\
\text { intervention test } \\
\text { was completed. } \\
\text { Data were } \\
\text { analyzed with the } \\
\text { SPSS system. }\end{array}$ & & & \\
\hline $\begin{array}{l}\text { Donahue, S., Schwien, M., \& LaVallee, D. (2019). Educating } \\
\text { the Emergency Department Staff on the } \\
\text { Identification and Treatment of Human } \\
\text { Trafficking Patients. JEN: Journal of Emergency } \\
\text { Nursing, 45(1), 16-23. } \\
\text { https://doi.org/10.1016/j.jen.2018.03.021 }\end{array}$ & 75 ED personnel. & $\begin{array}{l}\text { Quality } \\
\text { improvement with } \\
\text { pre-post evaluation } \\
\text { VA }\end{array}$ & $\begin{array}{l}\text { The intervention } \\
\text { included an } \\
\text { evidence-based } \\
\text { online training } \\
\text { module with pre- } \\
\text { and post- } \\
\text { intervention survey } \\
\text { evaluations. } \\
\text { HTEmergency.com } \\
\text { IRB deemed } \\
\text { review not } \\
\text { necessary for this } \\
\text { evidence-based } \\
\text { project. A Likert } \\
\text { scale questionnaire } \\
\text { was used to } \\
\text { evaluate } \\
\text { confidence. }\end{array}$ & $\begin{array}{l}\text { No theoretical } \\
\text { framework is } \\
\text { documented. } \\
\text { The intervention } \\
\text { involved } \\
\text { improving nurse } \\
\text { expertise and } \\
\text { skills; therefore, } \\
\text { the Benner } \\
\text { theory of novice } \\
\text { to an expert may } \\
\text { be applicable. }\end{array}$ & $\begin{array}{l}\text { Outcomes are } \\
\text { defined as } \\
\text { increased ED } \\
\text { personnel } \\
\text { confidence in } \\
\text { recognizing and } \\
\text { treating } \\
\text { potential human } \\
\text { trafficking } \\
\text { patients. } \\
\text { Implement a } \\
\text { screening tool } \\
\text { and flow chart } \\
\text { guidelines for } \\
\text { potential } \\
\text { patients. }\end{array}$ & $\begin{array}{l}\text { Confidence } \\
\text { increased } \\
\text { significantly from } \\
4 / 10 \text { to } 7 / 10 \text { for the } \\
\text { identification of } \\
\text { human trafficking } \\
\text { and increased from } \\
4 / 10 \text { to } 8 / 10 \text { for the } \\
\text { treatment of human } \\
\text { trafficking patients. } \\
\text { Understanding of } \\
\text { human trafficking } \\
\text { identification and } \\
\text { care increased from } \\
\text { less than } 50 \% \text { to } \\
93 \% \text {. }\end{array}$ \\
\hline $\begin{array}{l}\text { Du Mont, J., Macdonald S., White, M. Turner, L., White, D., } \\
\text { Kaplan., S., Smith, T. (2014). Client Satisfaction } \\
\text { with Nursing-led Sexual Assault and Domestic } \\
\text { Violence Services in Ontario. Journal of Forensic } \\
\text { Nursing, 10, 122-134. doi } \\
: 10.1097 / \text { JFN.0000000000000035 }\end{array}$ & $\begin{array}{l}1484 \text { sexual } \\
\text { assault patients } \\
35 \text { hospital-based } \\
\text { emergency } \\
\text { departments }\end{array}$ & $\begin{array}{l}\text { A unified, } \\
\text { consolidated study. } \\
\text { IIIA }\end{array}$ & $\begin{array}{l}\text { Train the Trainer. } \\
\text { Sexual Assault / } \\
\text { Domestic Violence } \\
\text { Treatment Center } \\
\text { (SA/DVTC) } \\
\text { standards of care, } \\
\text { practices, policies, } \\
\text { principles, and } \\
\text { values were used to } \\
\text { develop data } \\
\text { collection tools. } \\
\text { Client Satisfaction } \\
\text { survey tool with } \\
\text { 4-point Likert } \\
\text { scale. } \\
\text { Data analysis was } \\
\text { completed with the } \\
\text { SPSS system. }\end{array}$ & $\begin{array}{l}\text { A theoretical } \\
\text { framework was } \\
\text { not disclosed; } \\
\text { however, the } \\
\text { social- } \\
\text { ecological } \\
\text { Model may be } \\
\text { an appropriate } \\
\text { framework for } \\
\text { addressing the } \\
\text { social problem } \\
\text { of sexual assault } \\
\text { and domestic } \\
\text { violence. }\end{array}$ & $\begin{array}{l}\text { The study } \\
\text { included } \\
\text { evaluation of } \\
\text { Sexual Assault/ } \\
\text { Domestic } \\
\text { Violence } \\
\text { treatment center } \\
\text {-Emergency } \\
\text { services and } \\
\text { patient } \\
\text { characteristics \& } \\
\text { perspectives. }\end{array}$ & $\begin{array}{l}\text { Examination wait } \\
\text { time averaged } 1 \\
\text { hour and } 24 \\
\text { minutes. } \\
\text { Negative } \\
\text { perspective was } \\
\text { related to long wait- } \\
\text { times. } \\
\text { Recommendations } \\
\text { were made to ensure } \\
\text { 24hour timely care } \\
\text { available to reduce } \\
\text { wait time. } \\
\text { Recommendation } \\
\text { improve the } \\
\text { sensitivity of the ED } \\
\text { staff. } \\
\text { Recommendation to } \\
\text { increase privacy } \\
\text { such as separate } \\
\text { entrance and prompt } \\
\text { triage to private } \\
\text { area. }\end{array}$ \\
\hline
\end{tabular}




\begin{tabular}{|c|c|c|c|c|c|c|}
\hline $\begin{array}{l}\text { Du Mont, J., Solomon, S., Kosa, S. D., \& Macdonald, S. } \\
\text { (2018). Development and evaluation of sexual } \\
\text { assault training for emergency department staff in } \\
\text { Ontario, Canada. Nurse Education Today, 70, } \\
\text { 124-129. doi.org/10.1016/j.nedt.2018.08.025 }\end{array}$ & $\begin{array}{l}1,564 \text { staff from } \\
76 \text { Emergency } \\
\text { Departments } \\
\text { (ED) in acute } \\
\text { care hospitals }\end{array}$ & $\begin{array}{l}\text { Pilot improvement } \\
\text { project with } \\
\text { pre/post design for } \\
\text { comparison with } \\
\text { paired t-test. } \\
\text { Training test } \\
\text { compared with the } \\
\text { Mann Whitney U } \\
\text { test. } \\
\text { IVA }\end{array}$ & $\begin{array}{l}\text { Training and } \\
\text { Guidelines for the } \\
\text { treatment of sexual } \\
\text { assault patients. } \\
\text { The variables were } \\
\text { defined as } \\
\text { standardized, } \\
\text { consistent care for } \\
\text { sexual assault } \\
\text { patients for } \\
\text { compassionate and } \\
\text { supportive } \\
\text { nonjudgmental } \\
\text { care. } \\
\text { Questionnaires } \\
\text { were used for pre } \\
\& \text { post-intervention } \\
\text { data collection. } \\
\text { A 5-point Likert } \\
\text { scale was used to } \\
\text { measure the level } \\
\text { of agreement with } \\
\text { training and } \\
\text { perceived } \\
\text { competence. } \\
\text { Descriptive } \\
\text { statistics were } \\
\text { completed to } \\
\text { review } \\
\text { demographics. A } \\
\text { paired t-test was } \\
\text { used to compare } \\
\text { pre/post-training. }\end{array}$ & $\begin{array}{l}\text { Kilpatrick's } \\
\text { model was used } \\
\text { and is an } \\
\text { internationally } \\
\text { accepted } \\
\text { method of } \\
\text { developing and } \\
\text { evaluating } \\
\text { training by } \\
\text { examining } \\
\text { changes in } \\
\text { perceived } \\
\text { competence and } \\
\text { evaluation of } \\
\text { training content } \\
\text { and delivery. }\end{array}$ & $\begin{array}{l}\text { Outcomes are } \\
\text { defined as } \\
\text { increased staff } \\
\text { knowledge, } \\
\text { skills, and } \\
\text { confidence } \\
\text { about protocols } \\
\text { for the treatment } \\
\text { of sexual assault } \\
\text { patients for } \\
\text { increased } \\
\text { quality and } \\
\text { timelines of } \\
\text { care. }\end{array}$ & $\begin{array}{l}1564 \text { staff } \\
\text { participated in the } \\
\text { training. } 1402 \\
\text { completed the pre- } \\
\text { training } \\
\text { questionnaire. } 1385 \\
\text { completed post- } \\
\text { training } \\
\text { questionnaires } 1366 \\
\text { completed both pre/ } \\
\text { and post raining } \\
\text { questionnaires. } \\
\text { Statistically, } \\
\text { significant } \\
\text { improvement was } \\
\text { found in participant } \\
\text { confidence in } \\
\text { providing care to } \\
\text { sexual assault } \\
\text { patients by the } \\
\text { increased perception } \\
\text { of competency. }\end{array}$ \\
\hline $\begin{array}{l}\text { Egyud, A., Stephens, K., Swanson-Bierman, B., DiCuccio, } \\
\text { M., \& Whiteman, K. (2017). Implementation of } \\
\text { human trafficking education and treatment } \\
\text { algorithm in the emergency department: JEN. } \\
\text { Journal of Emergency Nursing, 43(6), 526-531. } \\
\text { doi.org/10.1016/j.jen.2017.01.008 }\end{array}$ & 102 staff & $\begin{array}{l}\text { Quality } \\
\text { improvement } \\
\text { initiative approved } \\
\text { by the IRB. } \\
\text { VA }\end{array}$ & $\begin{array}{l}\text { Education on } \\
\text { human trafficking } \\
\text { and a treatment } \\
\text { algorithm for the } \\
\text { ED staff. }\end{array}$ & $\begin{array}{l}\text { The Johns } \\
\text { Hopkins } \\
\text { Nursing } \\
\text { Evidence-Based } \\
\text { Practice Model } \\
\text { was used to } \\
\text { guide the project } \\
\text { and the Everett } \\
\text { M. Rogers } \\
\text { Change Model } \\
\text { to plan the } \\
\text { implementation } \\
\text { of practice } \\
\text { change. }\end{array}$ & $\begin{array}{l}\text { Outcome } \\
\text { definitions } \\
\text { emphasize the } \\
\text { importance of } \\
\text { formal } \\
\text { education, } \\
\text { screening, and } \\
\text { treatment } \\
\text { guideline for ED } \\
\text { personnel. } \\
100 \% \\
\text { compliance was } \\
\text { identified five } \\
\text { months after } \\
\text { implementation. }\end{array}$ & $\begin{array}{l}\text { Results: } 5 \text { months } \\
\text { after } \\
\text { implementation } \\
97 \% \text { of participants } \\
\text { reported a } \\
\text { commitment to } \\
\text { change practice. } \\
\text { Participants } \\
\text { reported } \\
\text { competency } \\
\text { improvement. } \\
\text { Educating the ED } \\
\text { staff on the use of a } \\
\text { screening tool and } \\
\text { treatment algorithm }\end{array}$ \\
\hline
\end{tabular}




\begin{tabular}{|c|c|c|c|c|c|c|}
\hline & & & & & $\begin{array}{l}85 \text { potential } \\
\text { trafficking } \\
\text { patients were } \\
\text { identified. Red } \\
\text { flags helped } \\
\text { identify } 20 \\
\text { patients (53\%), } \\
\text { and a silent } \\
\text { notification } \\
\text { system was used } \\
\text { to identify } 18 \\
\text { patients. } \\
\text { The intervention } \\
\text { was offered to } \\
100 \% \text { of } \\
\text { identified } \\
\text { patients. }\end{array}$ & $\begin{array}{l}\text { improved the } \\
\text { identification of } \\
\text { patients who are in } \\
\text { unsafe conditions. }\end{array}$ \\
\hline $\begin{array}{l}\text { Gilles, C., Manigart, Y., Rousseau, C., Libois, A., Gennotte, } \\
\text { A. F., \& Rozenberg, S. (2019). Implementation of } \\
\text { a protocol and staff educational sessions improves } \\
\text { the care of survivors of sexual assault. Maturitas, } \\
124,39-42 \text {. } \\
\text { doi.org/10.1016/j.maturitas.2019.03.004 }\end{array}$ & 362 patients & $\begin{array}{l}\text { The study protocol } \\
\text { was approved ty } \\
\text { the ethics } \\
\text { committee, and no } \\
\text { consent was } \\
\text { required since the } \\
\text { collected data was } \\
\text { anonymized. } \\
\text { Descriptive } \\
\text { statistics and the } \\
\text { X2 test were used } \\
\text { to identify } \\
\text { proportion } \\
\text { differences } \\
\text { between groups } \\
\text { with significance } \\
\text { set at 5\%. The } \\
\text { SPSS software was } \\
\text { used. A } \\
\text { retrospective chart } \\
\text { review was } \\
\text { completed. } \\
\text { The intervention } \\
\text { included training. } \\
\text { VA }\end{array}$ & $\begin{array}{l}\text { The educational } \\
\text { course provided for } \\
\text { ED staff focusing } \\
\text { on SA protocols } \\
\text { and computerized } \\
\text { chart. } \\
\text { Computerized } \\
\text { chart and care } \\
\text { protocol and } \\
\text { education- } \\
\text { Pre/posttest study } \\
\text { design. }\end{array}$ & $\begin{array}{l}\text { Theoretical } \\
\text { foundation } \\
\text { information was } \\
\text { not included. } \\
\text { The Brenner } \\
\text { novice to expert } \\
\text { theory could be } \\
\text { applicable as } \\
\text { nurses develop } \\
\text { expertise over } \\
\text { time with } \\
\text { ongoing } \\
\text { education and } \\
\text { experience. }\end{array}$ & $\begin{array}{l}\text { Optimal medical } \\
\text { was defined as } \\
\text { systematic } \\
\text { evaluation for } \\
\text { STDs, provision } \\
\text { f prophylactic } \\
\text { antibiotics, } \\
\text { pregnancy tests, } \\
\text { emergency } \\
\text { contraception as } \\
\text { well as follow } \\
\text { up for medical } \\
\text { and emotional } \\
\text { needs. }\end{array}$ & $\begin{array}{l}\text { Educational training } \\
\text { and care protocols } \\
\text { improved optimal } \\
\text { care from } 10 \% \text { to } \\
90 \% \text {. } \\
\text { For } 362 \text { patients } 337 \\
(93 \%) \text { had all } \\
\text { necessary } \\
\text { procedures, and } \\
\text { preventive measures } \\
\text { provided for } 325 \\
\text { patients }(90 \%)\end{array}$ \\
\hline $\begin{array}{l}\text { Greenbaum, V. J., Livings, M. S., Lai, B. S., Edinburgh, L., } \\
\text { Baikie, P., Grant, S. R., .. Self-Brown, S. } \\
\text { (2018b). Evaluation of a Tool to Identify Child } \\
\text { Sex Trafficking Patients in Multiple Healthcare } \\
\text { Settings. Journal of Adolescent Health, 63(6), }\end{array}$ & $\begin{array}{l}810 \text { participants } \\
\text { patients of sexual } \\
\text { violence }\end{array}$ & $\begin{array}{l}\text { A cross-sectional } \\
\text { observational } \\
\text { study. } \\
\text { Approved by IRB. } \\
\text { IIIA }\end{array}$ & $\begin{array}{l}\text { Educational } \\
\text { training and use of } \\
\text { a screening tool }\end{array}$ & $\begin{array}{l}\text { A theoretical } \\
\text { framework was } \\
\text { not disclosed; } \\
\text { however, the } \\
\text { social- } \\
\text { ecological }\end{array}$ & $\begin{array}{l}\text { Prevalence of } \\
\text { child sex } \\
\text { trafficking } \\
\text { identification } \\
\text { and care (CST) }\end{array}$ & $\begin{array}{l}\text { Findings include a } \\
\text { significant rate of } \\
\text { CST. } \\
\text { A } 6 \text {-item screening } \\
\text { helped identify CST }\end{array}$ \\
\hline
\end{tabular}




\begin{tabular}{|c|c|c|c|c|c|c|}
\hline $\begin{array}{l}\text { 745-752. } \\
\text { https://doi.org/10.1016/j.jadohealth.2018.06.032 }\end{array}$ & & & & $\begin{array}{l}\text { Model may be } \\
\text { an appropriate } \\
\text { framework for } \\
\text { addressing the } \\
\text { social problem } \\
\text { of CST. }\end{array}$ & & $\begin{array}{l}\text { and helped patient } \\
\text { prioritization }\end{array}$ \\
\hline $\begin{array}{l}\text { Jina, R., Jewkes, R., Christofides, N., \& Loots, L. (2014). A } \\
\text { cross-sectional study on the effect of post-rape } \\
\text { training on knowledge and confidence of health } \\
\text { professionals in South Africa. International } \\
\text { Journal of Gynecology and Obstetrics, 126(2), } \\
\text { 187-192. } \\
\text { https://doi.org/10.1016/j.ijgo.2014.02.011 }\end{array}$ & $\begin{array}{l}152 \text { health } \\
\text { professionals }\end{array}$ & $\begin{array}{l}\text { Cross-sectional } \\
\text { study } \\
\text { IIIA }\end{array}$ & $\begin{array}{l}\text { Training program } \\
\text { on post-rape sexual } \\
\text { assault care }\end{array}$ & $\begin{array}{l}\text { A theoretical } \\
\text { framework was } \\
\text { not documented; } \\
\text { however, the } \\
\text { social- } \\
\text { ecological } \\
\text { model is } \\
\text { appropriate to } \\
\text { address the } \\
\text { social issue of } \\
\text { rape and sexual } \\
\text { assault. }\end{array}$ & $\begin{array}{l}\text { Outcomes } \\
\text { include } \\
\text { increased } \\
\text { knowledge and } \\
\text { confidence for } \\
\text { ED nurses. }\end{array}$ & $\begin{array}{l}\text { Results found a } \\
\text { significant increase } \\
\text { in knowledge from } \\
40 \% \text { to } 51 \% \text { post- } \\
\text { training and } 17 \% \\
\text { increase in } \\
\text { confidence levels. }\end{array}$ \\
\hline $\begin{array}{l}\text { Jordan, K. S., Steelman, S. H., Leary, M., Varela-Gonzalez, } \\
\text { L., Lassiter, S. L., Montminy, L., \& Bellow, E. F. } \\
\text { (2019). Pediatric Sexual Abuse: An } \\
\text { Interprofessional Approach to Optimizing } \\
\text { Emergency Care. Journal of forensic nursing, } \\
\text { 15(1), 18-25. doi: } \\
\text { 10.1097/JFN.0000000000000232 }\end{array}$ & $\begin{array}{l}36 \text { participants } \\
\text { included ED } \\
\text { nurses, social } \\
\text { workers, } \\
\text { advanced } \\
\text { practice } \\
\text { providers, } \\
\text { behavioral health } \\
\text { workers, and law } \\
\text { enforcement. }\end{array}$ & $\begin{array}{l}\text { This was a } 2 \text { phase, } \\
\text { mixed-method pilot } \\
\text { study with } \\
\text { evidence-based } \\
\text { educational } \\
\text { intervention. } \\
\text { IIIA }\end{array}$ & $\begin{array}{l}\text { The intervention } \\
\text { included the } \\
\text { implementation of } \\
\text { a comprehensive } \\
\text { interprofessional / } \\
\text { education program. } \\
\text { A } 10 \text {-question pre } \\
\text { and posttest were } \\
\text { used. Descriptive } \\
\text { and inferential } \\
\text { statistics were } \\
\text { included in data } \\
\text { analysis. }\end{array}$ & $\begin{array}{l}\text { The study used } \\
\text { a theoretical } \\
\text { framework of } \\
\text { the Integrated } \\
\text { Change Model } \\
\text { for guidance. } \\
\text { The model } \\
\text { believes that } \\
\text { attributes of } \\
\text { knowledge, } \\
\text { attitude, self- } \\
\text { efficacy, and } \\
\text { skills increase } \\
\text { the potential for } \\
\text { goal } \\
\text { achievement. }\end{array}$ & $\begin{array}{l}\text { ED nurses must } \\
\text { have specialized } \\
\text { knowledge and } \\
\text { skills for } \\
\text { completing } \\
\text { trauma-informed } \\
\text { care of sexual } \\
\text { abuse patients. } \\
\text { Interprofessional } \\
\text { collaboration } \\
\text { and resource } \\
\text { usage are } \\
\text { necessary to } \\
\text { optimize care } \\
\text { for patients of } \\
\text { sexual abuse. }\end{array}$ & $\begin{array}{l}100 \% \text { of } \\
\text { participants } \\
\text { indicated that } \\
\text { additional education } \\
\text { would be beneficial } \\
\text { to their practice. } \\
\text { Statistical } \\
\text { significance was } \\
\text { found with a p- } \\
\text { value of }<0.01 \text {, } \\
\text { through a pre-test } \\
\text { mean score of } \\
62.2 \% \text { and a post- } \\
\text { test score of } 88.8 \% \text {. } \\
\text { The ED (ED) is } \\
\text { often a point of } \\
\text { entry for sexual } \\
\text { abuse patients. } \\
\text { Results found } \\
\text { significant } \\
\text { knowledge, } \\
\text { confidence, and } \\
\text { self-efficacy } \\
\text { increased for } \\
\text { emergency care } \\
\text { personnel post- } \\
\text { education } \\
\text { intervention. }\end{array}$ \\
\hline $\begin{array}{l}\text { Marchetti, C. A., Fantasia, H. C., \& Molchan, L. (2014), } \\
\text { Attitudes of Adult/Adolescent Sexual Assault }\end{array}$ & $\begin{array}{l}45 \text { SANE nurses } \\
\text { who provide care }\end{array}$ & $\begin{array}{l}\text { Qualitative } \\
\text { descriptive study. }\end{array}$ & $\begin{array}{l}\text { Education/ } \\
\text { training. An audit }\end{array}$ & $\begin{array}{l}\text { No theoretical } \\
\text { foundation was }\end{array}$ & $\begin{array}{l}\text { Outcome } \\
\text { definition }\end{array}$ & $\begin{array}{l}\text { ED nurses provide } \\
\text { care for SA patients; }\end{array}$ \\
\hline
\end{tabular}




\begin{tabular}{|c|c|c|c|c|c|c|}
\hline $\begin{array}{l}\text { Nurse Examiners and Caring for Younger Patients. } \\
\text { Journal of Emergency Nursing, 40(1), 39-45. } \\
\text { https://doi.org/10.1016/j.jen.2012.09.002 }\end{array}$ & $\begin{array}{l}\text { in the ED for } \\
\text { Sexual assault } \\
\text { patients age } 12 \\
\text { and older. } \\
\text { In } 6 \text { focus groups }\end{array}$ & $\begin{array}{l}\text { Audiotape recorded } \\
\text { and transcribed } \\
\text { group sessions. } \\
\text { IIIA }\end{array}$ & $\begin{array}{l}\text { included } \\
\text { transcripts, tapes, } \\
\text { and notes from } \\
\text { group sessions. } \\
\text { Data immersion } \\
\text { was followed by } \\
\text { content analysis. } \\
\text { Vivo coding } \\
\text { identified } \\
\text { categories for } \\
\text { SANE attitudes on } \\
\text { cross-training. } \\
\text { Two independent, } \\
\text { experienced } \\
\text { researchers verified } \\
\text { the study methods, } \\
\text { coding process, } \\
\text { and data analysis. }\end{array}$ & $\begin{array}{l}\text { listed. However, } \\
\text { the study } \\
\text { included efforts } \\
\text { to increase the } \\
\text { expertise of } \\
\text { nurses; } \\
\text { therefore, } \\
\text { Patricia } \\
\text { Brenner's } \\
\text { novice to the } \\
\text { expert model } \\
\text { may be } \\
\text { appropriate. }\end{array}$ & $\begin{array}{l}\text { Adequate } \\
\text { specialized } \\
\text { training/cross- } \\
\text { training is } \\
\text { needed to } \\
\text { provide care for } \\
\text { younger SA } \\
\text { patients. }\end{array}$ & $\begin{array}{l}\text { therefore, it is } \\
\text { essential that they } \\
\text { have adequate } \\
\text { training and support } \\
\text { to provide quality } \\
\text { physical care and } \\
\text { collection of } \\
\text { evidence in keeping } \\
\text { with regulatory } \\
\text { mandates. } \\
\text { Facilities should } \\
\text { have policies and } \\
\text { procedures for } \\
\text { providing care of } \\
\text { S/A patients as well } \\
\text { as the emotional } \\
\text { needs of ED nurses } \\
\text { who provide care. }\end{array}$ \\
\hline $\begin{array}{l}\text { Marks, S. A., Kaiser, L., \& McCleery, M. B. (2017). A Novel } \\
\text { Approach to Sexual Assault Nurse Examiner } \\
\text { Training: A Pilot Program. Clinical Simulation in } \\
\text { Nursing, 13(12), 595-600. } \\
\text { doi.org/10.1016/j.ecns.2017.07.002 }\end{array}$ & 19 Nurses & $\begin{array}{l}\text { Pilot study } \\
\text { IIIA }\end{array}$ & $\begin{array}{l}\text { Development and } \\
\text { implementation of } \\
\text { a multimethod, } \\
\text { simulation-based } \\
\text { training model to } \\
\text { streamline the } \\
\text { education process } \\
\text { using human } \\
\text { manikin-based } \\
\text { simulation. } \\
\text { SANE-A } \\
\text { preceptors } \\
\text { conducted } \\
\text { examinations and } \\
\text { competency } \\
\text { evaluations. } \\
\text { Experiences were } \\
\text { assessed with an } \\
\text { online } \\
\text { questionnaire, and } \\
\text { data was } \\
\text { aggregated, then } \\
\text { anonymously } \\
\text { reported. }\end{array}$ & $\begin{array}{l}\text { The theoretical } \\
\text { framework used } \\
\text { in this pilot } \\
\text { program is } \\
\text { Kolb's } \\
\text { experiential } \\
\text { learning cycle. }\end{array}$ & $\begin{array}{l}\text { Nurse } \\
\text { confidence in } \\
\text { caring for } \\
\text { completing } \\
\text { forensic } \\
\text { examinations. } \\
\text { (Reduced } \\
\text { training time } \\
\text { from } 11 \text { months } \\
\text { to } 2 \text { weeks, } \\
\text { reduced costs } \\
\text { from } \$ 2,500 \text { per } \\
\text { nurse to } \$ 1525, \\
\text { Reduced } \\
\text { attrition rate } \\
\text { from } 75 \% \text { to } \\
58 \% \text { post- } \\
\text { training. } \\
\text { Reduced } \\
\text { provision of } \\
\text { patient exams by } \\
\text { untrained staff } \\
\text { from } 60 \% \text { to } \\
0 \% \text { ), increased. }\end{array}$ & $\begin{array}{l}\text { Within one year, } 19 \\
\text { nurses were trained } \\
\text { to provide 24-hour } \\
\text { availability for } \\
\text { sexual assault } \\
\text { patients care in } 5 \\
\text { facilities with } \\
\text { emergency } \\
\text { departments by } \\
\text { using simulation- } \\
\text { based training. } \\
90 \% \text { of participants } \\
\text { reported a confident } \\
\text { or confident } \\
\text { inability to } \\
\text { complete sexual } \\
\text { assault } \\
\text { examinations. }\end{array}$ \\
\hline $\begin{array}{l}\text { Nielson, M. H., Strong, L. \& Stewart, J. G. (2015). Does } \\
\text { Sexual Assault Nurse Examiner (SANE) Training } \\
\text { Affect Attitudes of Emergency Department Nurses } \\
\text { Toward Sexual Assault Survivors?. Journal of } \\
\text { Forensic Nursing, } 11 \text { (3), 137-143. doi: } \\
\text { 10.1097/JFN.000000000000008 }\end{array}$ & 324 & $\begin{array}{l}\text { Qualitative study. } \\
\text { IIIA }\end{array}$ & $\begin{array}{l}\text { Comparison } \\
\text { questionnaire with } \\
\text { a } 25 \text { item, 5-point } \\
\text { Likert-type scale. } \\
\text { The process } \\
\text { compared nurses }\end{array}$ & $\begin{array}{l}\text { No theory was } \\
\text { listed in the } \\
\text { literature. } \\
\text { Patricia } \\
\text { Benners' theory } \\
\text { of novice to an }\end{array}$ & $\begin{array}{l}\text { SANE training } \\
\text { for ED nurses } \\
\text { increases } \\
\text { confidence in } \\
\text { skills for } \\
\text { providing care }\end{array}$ & $\begin{array}{l}1,503 \text { surveys were } \\
\text { sent to emergency } \\
\text { nurses association } \\
\text { nurses. } 406 \text { were } \\
\text { returned, and } 394 \\
\text { were completed }\end{array}$ \\
\hline
\end{tabular}




\begin{tabular}{|c|c|c|c|c|c|c|}
\hline & & & $\begin{array}{l}\text { with and without } \\
\text { SANE training. } \\
\text { Independent t-test } \\
\text { used to compare } \\
\text { perspectives. } \\
\text { Regression } \\
\text { analysis was used } \\
\text { to evaluate if } \\
\text { SANE training was } \\
\text { a predictor of the } \\
\text { nurse's perspective. }\end{array}$ & $\begin{array}{l}\text { expert might } \\
\text { correlate to the } \\
\text { process of } \\
\text { emergency } \\
\text { nurses } \\
\text { developing from } \\
\text { a novice level to } \\
\text { an expert level } \\
\text { through } \\
\text { education, } \\
\text { training, and } \\
\text { skill } \\
\text { development. }\end{array}$ & $\begin{array}{l}\text { to sexual assault } \\
\text { survivors. }\end{array}$ & $\begin{array}{l}\text { indicating a } 27 \% \\
\text { response rate. } \\
85.5 \% \text { of } \\
\text { respondents said } \\
\text { they were not } \\
\text { SANE trained, but } \\
\text { they care for Sexual } \\
\text { assault patients. } \\
\text { Findings show that } \\
\text { emergency nurses } \\
\text { care for sexual } \\
\text { assault patients } \\
\text { when SANE } \\
\text { services are not } \\
\text { available. SANE } \\
\text { trained nurses } \\
\text { scored higher in } \\
\text { positive attitudes } \\
\text { toward caring for } \\
\text { sexual assault } \\
\text { patients. } \\
\text { ED nurses should be } \\
\text { provided with } \\
\text { training to increase } \\
\text { skills, confidence, } \\
\text { and competence in } \\
\text { caring for sexual } \\
\text { assault patients. }\end{array}$ \\
\hline $\begin{array}{l}\text { Patterson, D., Resko, S., (2015), Is online Learning a Viable } \\
\text { Training Option for Teaching Sexual Assault } \\
\text { Forensic Examiners? Journal of Forensic Nursing, } \\
\text { 11, 181-189. doi: } \\
\text { 10.1097/JFN.0000000000000084 }\end{array}$ & 198 nurses & $\begin{array}{l}\text { One group pre/test } \\
\text { and post/ test } \\
\text { design. } \\
\text { IIIA }\end{array}$ & $\begin{array}{l}\text { A comprehensive } \\
12 \text { module online } \\
\text { sexual assault } \\
\text { forensic examiner } \\
\text { educational } \\
\text { training program. }\end{array}$ & $\begin{array}{l}\text { No Theoretical } \\
\text { model was } \\
\text { identified. } \\
\text { Patricia } \\
\text { Benner's theory } \\
\text { of novice to } \\
\text { expert relates to } \\
\text { the study with } \\
\text { online training } \\
\text { used to develop } \\
\text { nurses' } \\
\text { expertise levels. }\end{array}$ & $\begin{array}{l}\text { The outcome is } \\
\text { defined as the } \\
\text { attainment of } \\
\text { knowledge } \\
\text { regarding sexual } \\
\text { assault nurse } \\
\text { examiner }\end{array}$ & $\begin{array}{l}\text { Results found } \\
\text { significant } \\
\text { improvement in } \\
\text { knowledge of at } \\
\text { least } 25 \% \\
\text { knowledge increase } \\
\text { per module. }\end{array}$ \\
\hline $\begin{array}{l}\text { Rogers, A., McIntyre, S. L., Rossman, L., Solis, S., Bacon- } \\
\text { Baguley, T., \& Jones, J. (2019). The forensic rape } \\
\text { examination: Is colposcopy essential? The } \\
\text { American Journal of Emergency Medicine, 37(5), } \\
\text { 999-1000. doi: } \\
\text { http://dx.doi.org/10.1016/j.ajem.2018.10.015 }\end{array}$ & $\begin{array}{l}445 \text { sexual } \\
\text { assault patients }\end{array}$ & $\begin{array}{l}\text { A prospective } \\
\text { controlled trial. } \\
\text { IA }\end{array}$ & $\begin{array}{l}\text { Comparison of } \\
\text { Colposcopy, direct } \\
\text { visualization, and } \\
\text { nuclear staining } \\
\text { with toluidine blue } \\
\text { for the examination } \\
\text { of sexual assault } \\
\text { patients. }\end{array}$ & $\begin{array}{l}\text { No Theoretical } \\
\text { framework is } \\
\text { noted; however, } \\
\text { Kolb's } \\
\text { experiential } \\
\text { learning cycle } \\
\text { may be } \\
\text { applicable as a }\end{array}$ & $\begin{array}{l}\text { The outcome is } \\
\text { defined by the } \\
\text { number of } \\
\text { injuries } \\
\text { identified by } \\
\text { direct } \\
\text { visualization, } \\
\text { then the number }\end{array}$ & $\begin{array}{l}\text { Results indicated } \\
\text { that direct } \\
\text { visualization and } \\
\text { colposcopy } \\
\text { provided similar } \\
\text { results in the } \\
\text { identification of }\end{array}$ \\
\hline
\end{tabular}




\begin{tabular}{|c|c|c|c|c|c|c|}
\hline & & & $\begin{array}{l}\text { A Cooper surgical } \\
\text { Leisegang@ } \\
\text { colposcope with } \\
\text { 30x magnification } \\
\text { was used. }\end{array}$ & $\begin{array}{l}\text { cycle of } \\
\text { technique } \\
\text { evaluations } \\
\text { were conducted } \\
\text { to determine } \\
\text { effectiveness. }\end{array}$ & $\begin{array}{l}\text { of injuries } \\
\text { identified with } \\
\text { toluidine blue } \\
\text { day, then the } \\
\text { number } \\
\text { identified with } \\
\text { colposcopy } \\
\text { examination. }\end{array}$ & $\begin{array}{l}\text { injury in sexual } \\
\text { assault patients. }\end{array}$ \\
\hline $\begin{array}{l}\text { Scannell, M., Lewis-O'Connor, A., \& Barash, A. (2015). } \\
\text { Sexual Assault Simulation Course for Healthcare } \\
\text { Providers: Enhancing Sexual Assault Education } \\
\text { Using Simulation. Journal of Forensic Nursing, } \\
\text { 11(4), 190. doi: 10.1097/JFN.0000000000000089 }\end{array}$ & $120 \mathrm{ED}$ staff & $\begin{array}{l}\text { Quality } \\
\text { Improvement } \\
\text { project. } \\
\text { VA }\end{array}$ & $\begin{array}{l}\text { The interventions } \\
\text { included } \\
\text { interprofessional } \\
\text { education, training, } \\
\text { and simulation } \\
\text { skills development } \\
\text { and collaboration. } \\
\text { Pre / Post-test } \\
\text { questionnaire. }\end{array}$ & $\begin{array}{l}\text { The theoretical } \\
\text { framework is } \\
\text { not noted; } \\
\text { however, } \\
\text { Patricia } \\
\text { Benner's theory } \\
\text { of novice to an } \\
\text { expert might } \\
\text { correlate to the } \\
\text { process of } \\
\text { developing from } \\
\text { a novice level to } \\
\text { an expert level } \\
\text { through } \\
\text { interprofessional } \\
\text { education, } \\
\text { training, and } \\
\text { skill } \\
\text { development. }\end{array}$ & $\begin{array}{l}\text { Outcome goals } \\
\text { include } \\
\text { increased } \\
\text { interprofessional } \\
\text { collaboration, } \\
\text { increased } \\
\text { knowledge, and } \\
\text { skills }\end{array}$ & $\begin{array}{l}\text { Results of the post- } \\
\text { test indicate } \\
\text { increased } \\
\text { knowledge, skills, } \\
\text { and team } \\
\text { collaboration. }\end{array}$ \\
\hline $\begin{array}{l}\text { Scannell, M., MacDonald, A. E., Berger, A., \& Boyer, N. } \\
\text { (2018). The Priority of Administering HIV } \\
\text { Postexposure Prophylaxis in Cases of Sexual } \\
\text { Assault in an Emergency Department. Journal of } \\
\text { Emergency Nursing, 44(2), 117-122. } \\
\text { https://doi.org/10.1016/j.jen.2017.10.014 }\end{array}$ & $\begin{array}{l}18 \text { ED nursing } \\
\text { staff. }\end{array}$ & $\begin{array}{l}\text { Quality } \\
\text { Improvement } \\
\text { project. } \\
\text { VB }\end{array}$ & $\begin{array}{l}\text { Primary } \\
\text { intervention was } \\
\text { education with a } \\
\text { simulation training } \\
\text { course and } \\
\text { implementation of } \\
\text { a reference } \\
\text { checklist for } \\
\text { providing care to } \\
\text { sexual assault } \\
\text { patients. }\end{array}$ & $\begin{array}{l}\text { No Theoretical } \\
\text { framework is } \\
\text { noted. However, } \\
\text { Patricia } \\
\text { Benner's theory } \\
\text { of novice to an } \\
\text { expert might } \\
\text { correlate to the } \\
\text { process of } \\
\text { emergency } \\
\text { nurses } \\
\text { developing from } \\
\text { a novice level to } \\
\text { an expert level } \\
\text { through } \\
\text { education, } \\
\text { training, and } \\
\text { skill } \\
\text { development. }\end{array}$ & $\begin{array}{l}\text { Timely } \\
\text { administration } \\
\text { of post-exposure } \\
\text { prophylaxis } \\
\text { medications for } \\
\text { sexual assault } \\
\text { patients }\end{array}$ & $\begin{array}{l}\text { Training and } \\
\text { checklist usage } \\
\text { produced } \\
\text { improvement in } \\
\text { timeliness of } \\
\text { prophylaxis } \\
\text { medications and } \\
\text { increased screening } \\
\text { completion for } \\
\text { strangulation. }\end{array}$ \\
\hline $\begin{array}{l}\text { Tozzo, P., Ponzano, E., Spigarolo, G., Nespeca, P., \& } \\
\text { Caenazzo, L. (2018). Collecting sexual assault }\end{array}$ & $\begin{array}{l}122 \text { sexual } \\
\text { assault patients }\end{array}$ & $\begin{array}{l}\text { A retrospective } \\
\text { review was used to }\end{array}$ & $\begin{array}{l}\text { The retrospective } \\
\text { evaluation }\end{array}$ & $\begin{array}{l}\text { No theory was } \\
\text { documented, }\end{array}$ & $\begin{array}{l}\text { Outcomes are } \\
\text { the correlation }\end{array}$ & $\begin{array}{l}\text { Results found the } \\
\text { discrepancy in case }\end{array}$ \\
\hline
\end{tabular}




\begin{tabular}{|c|c|c|c|c|c|c|}
\hline $\begin{array}{l}\text { history and forensic evidence from adult women in } \\
\text { the emergency department: a retrospective study. } \\
\text { BMC health services research, 18(1), 383. } \\
\text { doi:10.1186/s12913-018-3205-8 }\end{array}$ & $\begin{array}{l}\text { examined in the } \\
\text { ED. }\end{array}$ & $\begin{array}{l}\text { identify the } \\
\text { effectiveness of } \\
\text { strategies for } \\
\text { collecting and } \\
\text { documenting the } \\
\text { history and } \\
\text { examination of } \\
\text { sexual assault } \\
\text { patients in the ED. } \\
\text { IIIA }\end{array}$ & $\begin{array}{l}\text { identified } \\
\text { recommended } \\
\text { improvement } \\
\text { interventions } \\
\text { include the } \\
\text { provision of } \\
\text { systematic } \\
\text { educational } \\
\text { training in } \\
\text { obtaining and } \\
\text { accurate } \\
\text { documenting } \\
\text { sexual assault } \\
\text { history in keeping } \\
\text { with established } \\
\text { protocols and } \\
\text { sympathetic } \\
\text { patient-centered } \\
\text { examination. }\end{array}$ & $\begin{array}{l}\text { however; Kolb's } \\
\text { experiential } \\
\text { learning cycle } \\
\text { may be } \\
\text { applicable as the } \\
\text { study evaluated } \\
\text { practice results } \\
\text { and identified } \\
\text { improvement } \\
\text { strategies }\end{array}$ & $\begin{array}{l}\text { or discrepancies } \\
\text { between } \\
\text { biological } \\
\text { evidence and the } \\
\text { documented } \\
\text { history of sexual } \\
\text { assault patients. } \\
\text { Another } \\
\text { outcome is } \\
\text { increased } \\
\text { accuracy in } \\
\text { collecting and } \\
\text { documenting } \\
\text { history and } \\
\text { evidence with } \\
\text { specially trained } \\
\text { professionals }\end{array}$ & $\begin{array}{l}\text { history and } \\
\text { biological evidence } \\
\text { and identified the } \\
\text { need for systematic } \\
\text { educational training } \\
\text { in obtaining and } \\
\text { documenting sexual } \\
\text { assault history. } \\
\text { Results also found } \\
\text { that protocols } \\
\text { should be } \\
\text { consistently } \\
\text { followed. }\end{array}$ \\
\hline $\begin{array}{l}\text { Whalen, M., Hansoti, B., Hsieh, Y.-H., Saheed, M., Signer, } \\
\text { D., \& Rothman, R. (2018). Translation of Public } \\
\text { Health Theory into Nursing Practice: Optimization } \\
\text { of a Nurse-Driven HIV Testing Program in the } \\
\text { Emergency Department. JEN: Journal of } \\
\text { Emergency Nursing, 44(5), 446-452. } \\
\text { https://doi.org/10.1016/j.jen.2018.02.002 }\end{array}$ & $\begin{array}{l}\text { 11,114 patients/ } \\
\text { HIV tests }\end{array}$ & $\begin{array}{l}\text { Retrospective } \\
\text { postimplementation } \\
\text { evaluation of } \\
\text { nurse-led ED } \\
\text { testing to optimize } \\
\text { HIV testing with } \\
\text { the education of } \\
\text { nurses, designated } \\
\text { nurse champion, } \\
\text { and optimal EHR. } \\
\text { The study period } \\
\text { was from } 2014 \text { to } \\
2016 . \\
\text { IIA }\end{array}$ & $\begin{array}{l}\text { The intervention } \\
\text { included ED } \\
\text { evaluation to } \\
\text { optimize HIV } \\
\text { testing with the } \\
\text { education of } \\
\text { nurses, designated } \\
\text { nurse champion, } \\
\text { and optimal EHR. } \\
\text { Data analysis was } \\
\text { completed using an } \\
\text { interrupted time- } \\
\text { series } \\
\text { autoregressive } \\
\text { integrated moving } \\
\text { average model } \\
\text { (ARIMA). } \\
\text { Ethical approval } \\
\text { was granted from } \\
\text { the Johns Hopkins } \\
\text { University } \\
\text { Institutional } \\
\text { Review Board } \\
\text { (IRB) for quality } \\
\text { assurance. }\end{array}$ & $\begin{array}{l}\text { No Theoretical } \\
\text { framework is } \\
\text { noted. However, } \\
\text { Patricia } \\
\text { Benner's theory } \\
\text { of novice to an } \\
\text { expert might } \\
\text { correlate to the } \\
\text { process of } \\
\text { emergency } \\
\text { nurses } \\
\text { increasing their } \\
\text { level of } \\
\text { expertise. }\end{array}$ & $\begin{array}{l}\text { The primary } \\
\text { outcome was the } \\
\text { identification } \\
\text { and provision of } \\
\text { HIV testing for } \\
\text { high-risk } \\
\text { patients in the } \\
\text { ED, including } \\
\text { patients of } \\
\text { sexual assault of } \\
\text { IPV in keeping } \\
\text { with CDC } \\
\text { protocols. }\end{array}$ & $\begin{array}{l}\text { Results found that } \\
\text { HIV testing for } \\
\text { patients, including } \\
\text { sexual assault and } \\
\text { IPV patients, is } \\
\text { improved with the } \\
\text { addition of ED } \\
\text { nurse education, } \\
\text { expanding from day } \\
\text { shift to 24-hour } \\
\text { service availability, } \\
\text { and designated } \\
\text { nurse champion. }\end{array}$ \\
\hline $\begin{array}{l}\text { Witt, J. S., Carlson, K., Colbert, S., Cordle, C., Hitchcock, K., } \\
\text { \& Kelly, P. J. (2015). SANE-A-PALOOZA: A } \\
\text { Clinical Immersion Experience to Close the Gap } \\
\text { for New Sexual Assault Nurse Examiners. Journal }\end{array}$ & 44 nurses & $\begin{array}{l}\text { Pre post- } \\
\text { intervention } \\
\text { evaluation was } \\
\text { completed with }\end{array}$ & $\begin{array}{l}\text { This intervention } \\
\text { provided a unified } \\
\text { didactic and skills } \\
\text { development }\end{array}$ & $\begin{array}{l}\text { The } \\
\text { constructivist } \\
\text { learning theory } \\
\text { for using }\end{array}$ & $\begin{array}{l}\text { Outcomes of the } \\
\text { intervention } \\
\text { resulted in a } \\
\text { knowledge }\end{array}$ & $\begin{array}{l}\text { Results show } \\
\text { statistically } \\
\text { significant } \\
\text { improvement in }\end{array}$ \\
\hline
\end{tabular}




\begin{tabular}{|c|c|c|c|c|c|c|}
\hline $\begin{array}{l}\text { of Forensic Nursing, 11(2), 101-106. } \\
\text { doi.org/10.1097/JFN.0000000000000069 }\end{array}$ & & $\begin{array}{l}\text { descriptive } \\
\text { statistics and } \\
\text { matched-pair t-tests } \\
\text { to evaluate } \\
\text { changes. } \\
\text { VA }\end{array}$ & $\begin{array}{l}\text { model for sexual } \\
\text { assault nurse } \\
\text { examiners. } \\
\text { Immediately } \\
\text { following a 40- } \\
\text { hour SANE } \\
\text { educational } \\
\text { program, an 8-hour } \\
\text { SANE skills } \\
\text { project was } \\
\text { completed. }\end{array}$ & $\begin{array}{l}\text { problem- } \\
\text { solving, } \\
\text { communication, } \\
\text { and integration } \\
\text { of new with old } \\
\text { knowledge was } \\
\text { used in this } \\
\text { study for } \\
\text { developing } \\
\text { expertise in the } \\
\text { provision of } \\
\text { care for sexually } \\
\text { assaulted } \\
\text { patients. } \\
\text { The SAFE } \\
\text { CARE model } \\
\text { was used for } \\
\text { maintaining } \\
\text { forensic nursing } \\
\text { competency. }\end{array}$ & $\begin{array}{l}\text { increase from } \\
10.1 \text { to } 11.5 \\
\text { with; <0.001. } \\
\text { Confidence } \\
\text { increase from } \\
15.0 \text { to } 20.1 \\
\text { with p<0.000. } \\
\text { Outcomes were } \\
\text { determined with } \\
\text { a pre- and post- } \\
\text { evaluation. } \\
\text { Outcome criteria } \\
\text { included patient } \\
\text { education, } \\
\text { participation } \\
\text { confidence in } \\
\text { clinical skills, } \\
\text { and program } \\
\text { satisfaction. } \\
\text { Preceptors were } \\
\text { used to } \\
\text { providing and } \\
\text { evaluating skills } \\
\text { demonstration } \\
\end{array}$ & $\begin{array}{l}\text { knowledge and } \\
\text { confidence in } \\
\text { providing care for } \\
\text { sexually assaulted } \\
\text { patients. }\end{array}$ \\
\hline $\begin{array}{l}\text { Yildiz, T., Selimen, D., \& Dogan, D. (2014). A Study } \\
\text { Comparing the Pre- and Post-Training Knowledge } \\
\text { of Emergency Department Nurses in Turkey for } \\
\text { the Diagnosis of Physically Abused Women. } \\
\text { Journal of Family Violence, 29(5), 519-525. } \\
\text { https://doi.org/10.1007/s10896-014-9608-3 }\end{array}$ & 49 ED nurses & $\begin{array}{l}\text { Quality } \\
\text { improvement with } \\
\text { pre and post } \\
\text { evaluation of ED } \\
\text { nurses 'knowledge. } \\
\text { Research } \\
\text { permission and } \\
\text { ethics approval } \\
\text { were obtained. } \\
\text { VA }\end{array}$ & $\begin{array}{l}\text { The intervention } \\
\text { included an } \\
\text { educational } \\
\text { seminar regarding } \\
\text { the identification } \\
\text { of sexual violence, } \\
\text { abuse, and related } \\
\text { symptoms. }\end{array}$ & $\begin{array}{l}\text { The intervention } \\
\text { intended to } \\
\text { increase nurses' } \\
\text { expertise, } \\
\text { therefore, } \\
\text { Patrician, } \\
\text { Benners' novice } \\
\text { to expert theory } \\
\text { may be } \\
\text { applicable. }\end{array}$ & $\begin{array}{l}\text { Outcomes } \\
\text { include the } \\
\text { determination of } \\
\text { increased } \\
\text { knowledge for } \\
\text { emergency } \\
\text { nurses about } \\
\text { signs and } \\
\text { symptoms of } \\
\text { sexual violence. }\end{array}$ & $\begin{array}{l}\text { Results indicated } \\
\text { the ED nurses' } \\
\text { knowledge scores } \\
\text { increased from a } \\
\text { baseline of } \\
27.79+4.69 \text { before } \\
\text { the intervention to } \\
47.57+1.7 \text { post- } \\
\text { intervention. }\end{array}$ \\
\hline
\end{tabular}


Appendix B

\begin{tabular}{|c|c|c|c|c|c|c|c|}
\hline Citation & Question & Search Strategy & $\begin{array}{l}\text { Inclusion/ } \\
\text { Exclusion Criteria }\end{array}$ & $\begin{array}{l}\text { Data Extraction and } \\
\text { Analysis }\end{array}$ & Key Findings & $\begin{array}{l}\text { Recommendation/ } \\
\text { Implications }\end{array}$ & $\begin{array}{l}\text { Level of } \\
\text { Evidence }\end{array}$ \\
\hline $\begin{array}{l}\text { Adams, P. \& Hulton, L. (2016). } \\
\text { The Sexual Assault Nurse } \\
\text { Examiner's Interactions Within the } \\
\text { Sexual Assault Response Team. } \\
\text { Advanced Emergency Nursing } \\
\text { Journal, 38 (3), 213-227. doi: } \\
\text { 10.1097/TME.0000000000000112. }\end{array}$ & \begin{tabular}{|l|} 
Does \\
collaboration \\
between the \\
SANE and the \\
SART improve \\
the care of \\
sexual assault \\
patients?
\end{tabular} & $\begin{array}{l}\text { The search strategy was } \\
\text { implemented in three stages and } \\
\text { included CINAHL and PubMed. } \\
\text { Initially, the search was within } \\
\text { the past five years then } \\
\text { increased to10 years plus hand } \\
\text { search of the Journal of } \\
\text { Forensic Nursing }\end{array}$ & \begin{tabular}{|l|} 
Inclusion: \\
English language and \\
peer-reviewed articles. \\
Keywords included: \\
sexual assault nurse \\
examiner "SANE" alone \\
and paired with "sexual \\
assault response Team," \\
"SART": SANES, \\
medical personnel, \\
forensic examiners and \\
SART members, \\
criminal justice, law \\
enforcement, and sane \\
program coordinators. \\
Exclusion: \\
Dissertations, books, \\
SANE programs, \\
policies and protocols, \\
evidence collecting, \\
prevention, bystander, \\
elder and child abuse, \\
and patients-related \\
care. \\
582 articles were \\
examined, 570 were \\
excluded, 12 articles \\
selected for the \\
systematic review.
\end{tabular} & \begin{tabular}{|l|} 
Selected articles were \\
read and summarized on \\
a worksheet that enabled \\
verification of the key \\
concepts, design, \\
themes, weaknesses, \\
and recommendations. \\
A level of evidence was \\
assigned to each \\
research study to \\
identify quality and \\
strength. \\
Article summaries were \\
transcribed on a \\
systematic matrix, \\
including author, \\
journal, design, data \\
collection evidence \\
level, sample size, \\
results, and summary.
\end{tabular} & $\begin{array}{l}\text { Results found } \\
\text { knowledge gaps } \\
\text { between the SANE and } \\
\text { the SART, including } \\
\text { attitude, behavior, and } \\
\text { satisfaction with the } \\
\text { team. } \\
\text { SANE's role should } \\
\text { focus on examination, } \\
\text { forensic evidence } \\
\text { collection, and be a fact } \\
\text { or expert witness for } \\
\text { testimony. Need for } \\
\text { improvement in the } \\
\text { SANE relationship with } \\
\text { attorneys. Advocates' } \\
\text { role should focus on } \\
\text { support and crisis } \\
\text { intervention. } \\
\text { Conflict and turf wars } \\
\text { cause challenges in the } \\
\text { SART. }\end{array}$ & $\begin{array}{l}\text { Recommended more research } \\
\text { in a collaborative process. } \\
\text { Improve Success of the } \\
\text { SART with improved } \\
\text { communication, debriefing } \\
\text { meetings, feedback, conflict } \\
\text { resolution, value, and } \\
\text { appreciation for } \\
\text { interprofessional team, joint } \\
\text { training, respect, and shared } \\
\text { goals. } \\
\text { THE National SART tool kit } \\
\text { recommended as a reference. } \\
\text { For Emergency rooms } \\
\text { without a SANE program, } \\
\text { there is a National Protocol } \\
\text { for Sexual Assault Medical } \\
\text { Forensic Examination for } \\
\text { guidance. }\end{array}$ & |III \\
\hline $\begin{array}{l}\text { Hemmings, S., Jakobowitz, S., } \\
\text { Abas, M., Bick, D., Howard, L. } \\
\text { M., Stanley, N., .. Oram, S. } \\
\text { (2016). Responding to the health } \\
\text { needs of survivors of human } \\
\text { trafficking: A systematic review. } \\
\text { BMC Health Services Research, } 16 \\
\text { doi.org/10.1186/s12913-016-1538- } \\
8\end{array}$ & $\begin{array}{l}\text { Do health care } \\
\text { provider } \\
\text { training and } \\
\text { protocols } \\
\text { improve the } \\
\text { effectiveness of } \\
\text { identifying, } \\
\text { referring, and } \\
\text { caring for } \\
\text { human/ sex } \\
\text { trafficking? }\end{array}$ & $\begin{array}{l}\text { 16 biomedical and social } \\
\text { science databases and } 21 \text { grey } \\
\text { literature websites were } \\
\text { searched from January } 1^{\text {st, }} 1990 \\
\text { to February } 2015 \text {. } \\
\text { Electronic searches were } \\
\text { supplemented with reference list } \\
\text { screening and forward citation } \\
\text { tracking. } \\
\text { A combination of vocabulary } \\
\text { and free text terms were used in } \\
\text { the database search, including } \\
\text { human trafficking, sex } \\
\text { trafficking, health services, }\end{array}$ & \begin{tabular}{|l|}
9,356 documents were \\
identified for the title, \\
and abstract screen, 510 \\
documents for the full- \\
text screen, 44 papers \\
were selected. \\
Inclusion criteria \\
included adults or \\
children who had been \\
trafficked, reported \\
health interventions, \\
focus on primary, \\
secondary tertiary, or \\
emergency heath \\
settings.
\end{tabular} & \begin{tabular}{|l|} 
Data were extracted into \\
a standardized form and \\
divided between 2 \\
reviewers. Each \\
reviewer independently \\
and randomly extracted \\
data form $25 \%$ of \\
papers, and no \\
differences were \\
identified. Extraction \\
included study \\
population, \\
characteristics, \\
trafficked person \\
understanding,
\end{tabular} & $\begin{array}{l}\text { Identified concerns } \\
\text { included: promoting } \\
\text { disclosure } \\
\text { Providing care, ensuring } \\
\text { safety, supporting } \\
\text { recovery, working in } \\
\text { partnerships, and } \\
\text { developing services. }\end{array}$ & $\begin{array}{l}\text { Training for healthcare } \\
\text { professionals to include } \\
\text { information about referral } \\
\text { and support options for } \\
\text { trafficked patients, and } \\
\text { national reporting } \\
\text { requirements, } \\
\text { Establish clear referral } \\
\text { pathways, and information } \\
\text { sharing protocols, Adopt } \\
\text { trauma-informed, culturally } \\
\text { sensitive approaches, } \\
\text { complete comprehensive } \\
\text { physical assessments, create }\end{array}$ & IIA \\
\hline
\end{tabular}




\begin{tabular}{|c|c|c|c|c|c|c|c|}
\hline Citation & Question & Search Strategy & $\begin{array}{l}\text { Inclusion/ } \\
\text { Exclusion Criteria }\end{array}$ & $\begin{array}{l}\text { Data Extraction and } \\
\text { Analysis }\end{array}$ & Key Findings & $\begin{array}{l}\text { Recommendation/ } \\
\text { Implications }\end{array}$ & $\begin{array}{l}\text { Level of } \\
\text { Evidence }\end{array}$ \\
\hline & & $\begin{array}{l}\text { hospital, and emergency health } \\
\text { personnel. }\end{array}$ & $\begin{array}{l}\text { No language } \\
\text { restrictions. } \\
\text { Exclusions included } \\
\text { editorials, opinions, and } \\
\text { textbooks. } \\
\\
\end{array}$ & $\begin{array}{l}\text { expectations, and } \\
\text { experiences of health } \\
\text { needs, care provision, } \\
\text { and interventions. 25\% } \\
\text { of screenings and full } \\
\text { text were checked for } \\
\text { agreement and } \\
\text { consistency. } \\
\text { Independent assessment } \\
\text { of methodological } \\
\text { quality was completed } \\
\text { by two reviewers with } \\
\text { checklists from Joanna } \\
\text { Briggs Institute. } \\
\text { The analysis was } \\
\text { completed by two } \\
\text { reviewers using } \\
\text { framework analysis. A } \\
\text { matrix-based method } \\
\text { constructed themed } \\
\text { groups for data } \\
\text { categorization to } \\
\text { increase rigor. The } \\
\text { analysis included repeat } \\
\text { data reading, accuracy } \\
\text { checking, concept } \\
\text { charting, and } \\
\text { visualization of } \\
\text { overarching themes, } \\
\text { which were drafted to a } \\
\text { conceptual framework. } \\
\text { The framework was } \\
\text { revised with the } \\
\text { emergence of new or } \\
\text { merged categories. } \\
\text { Two reviewers screened } \\
\text { titles and abstracts } \\
\text { independently. Two } \\
\text { reviewers assessed full } \\
\text { text of potentially } \\
\text { eligible studies. } \\
\text { Consensus decision } \\
\text { resolved disagreements } \\
\text { or a } 3^{\text {rd }} \text { reviewer } \\
\text { consulted. } \\
\text { a }\end{array}$ & & $\begin{array}{l}\text { and use referral networks, } \\
\text { include. }\end{array}$ & \\
\hline
\end{tabular}




\section{Appendix C}

Strengths Weaknesses Opportunities and Threats Analysis

Internal Forces (Project)

Strengths (Internal)

Leadership support

The facility and the staff are interested in improving knowledge, skills, and confidence

The facility values meeting the needs of patients who present to the emergency department

Required equipment is in stock

An active continuing education program in place with the Florida Board of nursing to facilitate program development and sustainability

Weaknesses (Internal)

The challenge of scheduling ED staff time to attend education and training

The lack of available educational training material

The limited number of only one current staff member who has been trained in SAFE

The absence of protocols, policies, and reference material
External Forces (Organization or Environment)

Opportunities (External)

The opportunity to schedule part of the training in an online or home-study format and part of the training on-site

The opportunity to network with the county SART team for support

The opportunity to build on this scholarly project and implement additional training for patients of violent crimes

Threats (External)

Staff turnover. If nurses resign from current ED positions, that could impact the ability to schedule staff for training or skills development.

Regulatory requirements for specific training on care for sexual assault patients may be viewed as a threat.

Negative ratings for emergency department timelines and effectiveness of care regarding wait times 
Appendix D

Project Schedule

\begin{tabular}{|c|c|c|c|c|c|c|c|c|}
\hline \multirow[b]{2}{*}{ Activity } & \multicolumn{8}{|c|}{ NUR7802 (Sept. 16 - Dec. 2019) } \\
\hline & $\begin{array}{l}\frac{N}{1} \\
\frac{\pi}{D} \\
\frac{d}{3}\end{array}$ & 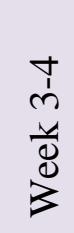 & 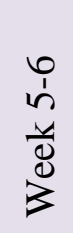 & $\begin{array}{l}\infty \\
1 \\
i \\
i v \\
\mathbb{D} \\
3\end{array}$ & $\begin{array}{l}\frac{0}{1} \\
a \\
\frac{y}{0} \\
3 \\
3\end{array}$ & $\begin{array}{l}\stackrel{v}{1} \\
\beth \\
y \\
\frac{1}{0} \\
3\end{array}$ & $\begin{array}{l} \pm \\
\dot{1} \\
\stackrel{y}{y} \\
\frac{y}{d} \\
\frac{d}{3}\end{array}$ & $\begin{array}{l}n \\
\frac{y}{8} \\
\frac{0}{3}\end{array}$ \\
\hline Preceptor collaboration as needed & & $\mathrm{X}$ & & $\mathrm{X}$ & & $\mathrm{X}$ & & $\mathrm{X}$ \\
\hline Interprofessional team collaborations / status reports & $\mathrm{X}$ & & $\mathrm{X}$ & & $\mathrm{X}$ & & $\mathrm{X}$ & \\
\hline Project proposal & $\mathrm{X}$ & & & & & & & \\
\hline Review IRB proposal approval process & $\mathrm{X}$ & & & & & & & \\
\hline Collect \& complete IRB documents /signatures & $\mathrm{X}$ & & & & & & & \\
\hline Submit the proposal to IRB Week 2 & $\mathrm{X}$ & & & & & & & \\
\hline Generate enthusiasm and celebrate achievements & $\mathrm{X}$ & $\mathrm{X}$ & $\mathrm{X}$ & $\mathrm{X}$ & $\mathrm{X}$ & $\mathrm{X}$ & $\mathrm{X}$ & $\mathrm{X}$ \\
\hline Prepare training material & & $\mathrm{X}$ & & & & & & \\
\hline Obtain BON CE credit for education program & $\mathrm{X}$ & $\mathrm{X}$ & & & & & & \\
\hline Allow time for IRB approval & & & $\mathrm{X}$ & & & & & \\
\hline Submit to facility IRB after USA approval & & & $\mathrm{X}$ & & & & & \\
\hline Schedule and post-training dates, times \& location & & & $\mathrm{X}$ & $\mathrm{X}$ & $\mathrm{X}$ & $\mathrm{X}$ & $\mathrm{X}$ & \\
\hline Begin implementation and celebrate Start up & & & $\mathrm{X}$ & & & & & \\
\hline Education \& training for ED Staff (pre/post-test) & & & $\mathrm{X}$ & $\mathrm{X}$ & $\mathrm{X}$ & $\mathrm{X}$ & & \\
\hline Post guidelines at ED and in training sessions & & & $\mathrm{X}$ & $\mathrm{X}$ & $\mathrm{X}$ & $\mathrm{X}$ & $\mathrm{X}$ & \\
\hline Audit with feedback \& remedial training & & & $X$ & $\mathrm{X}$ & $\mathrm{X}$ & $\mathrm{X}$ & $\mathrm{X}$ & \\
\hline Data Collection & & & $\mathrm{X}$ & $\mathrm{X}$ & $\mathrm{X}$ & $\mathrm{X}$ & $\mathrm{X}$ & \\
\hline Data Analysis with IBM SPSS system & & & & & & & & $\mathrm{X}$ \\
\hline Project Closure & & & & & & & & $\mathrm{X}$ \\
\hline
\end{tabular}


Appendix E

Sexual Assault Forensic Examination Pre-test

Name: Date:

Select the BEST answer for each question.

1. What is the maximum time interval from the time of the event until the time of examination for Acute Sexual Assault Cases at our facility?

a. 24 hours

b. 48 hours

c. $\quad 72$ hours

d. 96 hours

2. A buccal/standard swab is obtained in order to:

a. Collect standard oral evidence when there has been penile/oral penetration

b. Collect the patient's DNA for a DNA standard sample

c. Provide standard evidence when there has been vaginal penetration

d. Provide standard evidence when there has been a drug-facilitated sexual assault

3. In our county, the only clothing the Forensic Examiner collects for evidence from a sexual assault is underwear.

a. True b. False

4. At our hospital, when an interpreter is needed for services, be sure to document their name/date/time on the Sexual Assault Forms.

a. True b. False

5. Oral swabs and smears are obtained:

a. From every sexual assault patient

b. From a patient who had penile/vaginal penetration

c. From a patient who was forced to engage in oral sex on the assailant

d. From a female patient who had oral sex performed on her

6. In sexual assault forensic examinations, a Wood's lamp (ultraviolet light source) is used to fluoresce \& identify:

a. Sweat

b. Urine

c. Semen

d. Vaginal secretions 
7. At the end of a case, you may review the sexual assault report and turn over all evidence from the case to any law enforcement officer.

a. True b. False

8. Which of the following samples are collected for Toxicology if a drug-facilitated sexualassault is suspected?

a. Urine sample only

b. Blood and saliva samples

c. Urine and blood samples

d. Blood sample only

9. An injury is described as a laceration if:

a. There is a defect in soft tissues resulting from blunt force (tear, rip, crush, overstretch)

b. There is leakage of blood from vessels into soft tissues after sufficient force has been applied to distort soft tissue and to ear vessels

c. It is a localized mass of blood that is relatively or completely confined within an organ.

d. The injury was caused by a separation of tissue by a sharp object

10. All forensic specimens are packaged in:

a. Plastic bags only to protect against contamination

b. Paper bags only to prevent overgrowth of bacteria and mold

c. Plastic bags for damp/wet materials and paper bags for dry materials

d. Plastic bag for urine toxicology (urine cup inside hazardous materials plastic bag) \& everything else is in paper bags

11. When interviewing a patient, it is important to document every detail related to the case, such as specific time/location of the assault, weapons used and a detailed physical description of the assailant(s).
a. True b. False

12. In order to have a Forensic Examination at our hospital, a patient must report the sexual assault to a law enforcement agency.

a. True b. False

13. DCF and law enforcement agencies must be contacted in which of the following cases?

a. Only for adult patients who wish to report the sexual assault

b. For all minors, whether or not they are accompanied by a parent/guardian.

c. For all cases

d. For suspected elderly abuse cases

e. B \& D only 
14. Adult patients of sexual assaults are treated prophylactically with:

a. Pen-V-K 500mg orally every 8 hours for 5 days

b. Penicillin G 1.2 million units IM in each buttock for a single dose

c. Ciprofloxacin $500 \mathrm{mg}$ orally in a single dose

d. Ceftriaxone $125 \mathrm{mg}$ IM, Metronidazole 2 grams orally and Azithromycin 1 gram orally

15. When you receive a subpoena from a defense attorney for deposition of a sexual assault case, who should accompany you to the deposition?

a. Hospital's Risk Management attorney

b. You don't need anyone to represent your interests

c. An Assistant State Attorney

d. Your personal attorney

16. Concerning advocacy and social services for patients of sexual assault:

a. All sexual assault patients should be referred to a social worker for counseling

b. Only crying, hysterical patients who were raped by a stranger are referred for counseling

c. Counseling services are provided on a sliding scale fee basis

d. Only minors need counseling after a sexual assault

17. Any patients ( $\geq 12$ years of age) of sexual assault can sign their own consent for a forensic examination and treatment for STIs at our hospital.

a. True b. False

18. When treating adult female patients of sexual assault, which of the medications are safe to give in pregnancy?

a. Penicillin

b. Ceftriaxone

c. Azithromycin \& Metronidazole

d. None of them

e. All of them

19. After collecting all specimens, take the tube containing the vaginal aspirate to the microscope, apply one drop on a slide, cover with coverslip view under high magnification for motile sperm.

a. True b. False

20. Approximately what percent of sexual assaults in women are reported to law enforcement?

a. $80 \%$

b. 60

c. 40

d. $20 \% \quad$ (Fitzpatrick, Ta, Lenchus, Arheart, Rosen, \& Birnbach, 2012) 


\section{Appendix F}

\section{Forensic Examination Simulation Checklist}

Forensic Examination Procedures Simulation Checklist

Name: Case Type:

(please print)

Date: Instructor:

$2=$ Completely performed

$1=$ Partially performed

$0=$ No attempt N/A - not applicable

\section{PATIENT SCENARIO}

1. Review patient history with MA/PCT

2. Enter Exam Room \& Wash Hands

3. Introduce Self

4. Identify Patient \& verify demographic information on face sheet/chart labels

5. Identify Allergies \& Current Medications; Document on Nursing Flowsheet

6. Obtain vital signs; Review if obtained by MA/PCT

7. Obtain written consent for Sexual Assault Exam.

8. If it's a Reporting Case, document Police Department/Detective and Case \#

9. Obtain Personal Health History

10. Obtain History of Assault

11. Obtain consent for STI screening \& Prophylactic Treatment (as indicated)

12. Explain steps in physical examination, ask patient if she/he has any questions

13. Patient changes into hospital gown; obtain underwear if indicated and place in brown paper evidence bag separate from other specimens. Perform General Examination (Specific sections if indicated)

14. Wearing exam gloves, perform Head to Toe Exam

15. Oral Swabs \& Smears

16. Standard Buccal Swab Collection

17. External Genital/Rectal Exam \& Wood's Lamp Exam (if indicated): Pelvic Exam in Females/Genital Exam in Males

18. Pubic Hair Combings

19. Dried Fluids Evidence Collection

20. Vaginal Swabs \& Smear

21. Cervical Swabs \& Smear (Chlamydia/GC if $<18 \mathrm{y} / \mathrm{o}$ )

22. Vaginal Aspirate

23. Penile Swabs \& Smear (Chlamydia/GC if $<18 \mathrm{y} / \mathrm{o}$ )

24. Rectal Swabs \& Smear (GC if $<18$ y/o) 
25. Fingernail Scrapings

26. Toxicology Screening (Urine)

27. Consent for Estrogen Therapy \&Pregnancy Prophylaxis

28. Pregnancy \& STI Screening \& Treatment

29. Digital Photography/Colposcopy

30. Whole Blood Specimens:

Lavender Top Tube to Crime Lab

One red-top tube for RPR (our lab) Tiger top for CMP (if PEP elected)

When indicated, 2 grey top tubes as described in the toxicology section

31. Paper Evidence Bag (s) Proper sealing \& Labeling

32. Documentation: Pages 1 \& 2 of Sexual Assault Form, Flowsheet

Explain steps in physical examination ask the patient if she/he has any questions

33. Proper handoff of evidence to Law Enforcement or locked in specimen refrigerator to maintain chain of custody of evidence

34. Contact (**specific to your facility) for HIV consent, Testing \& F/U testing at 3 months \& 6 months.

Date :

Time:

Faculty assessment of participants'

confidence:

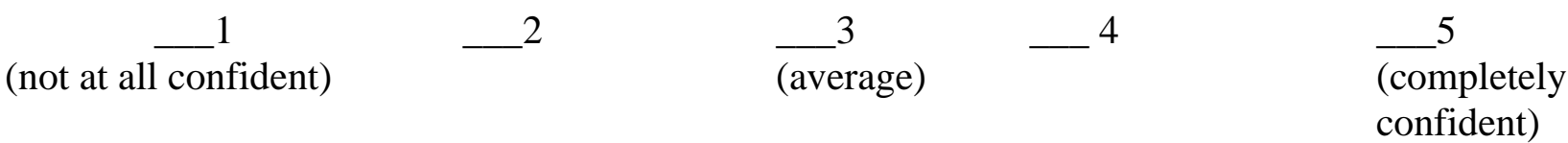

Faculty assessment of participants'

competence:

(not at all, needs several more cases) $\overline{1}^{2} \quad \overline{\text { (average) }}^{3} \quad-4 \quad{ }^{5}$ competent, no further supervision needed)

(Fitzpatrick, Ta, Lenchus, Arheart, Rosen, \& Birnbach, 2012) 


\author{
Appendix G \\ Education Outline Minimum Training Recommendations \\ National Training Standards for Sexual Assault Medical Forensic Examiners
}

U.S. Department of Justice Office on Violence Against Women

1. Neurobiology of trauma

2. The role and importance of multidisciplinary collaboration in sexual assault, including:

a. healthcare providers

b. Sexual assault and sexual abuse advocacy

c. Law enforcement $\mathrm{d}$. adult/child protective services

3. The pediatric, adolescent and adult sexual assault and sexual abuse medical forensic examination

a. Informed consent and assent

b. Language

i. Behavioral descriptors

ii. Terminology, anatomy, and definitions

iii. Avoiding the use of legal terminology (vs. medical terminology)

iv. Using factual terms rather than value judgments in language use

v. Avoiding coercion and/or judgment

c. Mandatory reporting

d. Patient options for reporting to law enforcement

e. History taking in sexual assault and abuse

f. Sexual assault and sexual abuse evidence collection

i. The evidence collection kit

ii. Evidence identification

iii. Specimen collection and basic forensic principles

1. Changing gloves between body areas

2. Drying specimens

3. Handling, labeling, and packaging samples

4. Toxicology specimens

5. Other specialized specimen handling

iv. Specimen handling, the chain of custody

g. Documentation of the examination

i. Forms

ii. Body maps

h. Medical management

i. STD treatment standards and recommendations for prophylaxis

ii. HIV risk evaluation, screening, and recommendations for prophylaxis

iii. Pregnancy risk, evaluation, and care

iv. Injury evaluation, treatment, and documentation

1. Basic mechanisms of injury 
2. Strangulation evaluation

v. Other medical management issues (tetanus)

i. Discharge planning, safety planning, suicide risk assessment, and referrals for postassault care and follow-up needs

j. Management of documentation/records

i. Storage of examination records

ii. Release of records

iii. Retention of records

k. Court testimony

i. Subpoena responses

ii. Testimony basics

(U.S. Department of Justice, 2018). 


\section{Appendix $\mathrm{H}$}

\section{Guidelines for Collection of Evidence from Patients of Sexual Assault}

Each step listed below is important and will provide essential evidence. To ensure that the chain of custody is intact, the examiner must TAPE, SEAL, and INITIAL each of the items within the kit. Remember that the patient has the right to refuse any part of the examination.

1. Empty the contents of the kit onto a clean surface designated for evidence collection. Remove any items that will not be collected. DO NOT return any unused items to the kit.

2. Have patients undress over a clean sheet of paper. Place the underwear in the designated bag — seal and initial. Place all other clothing items into a separate paper bag. Seal and initial. Identify all bags with the patients 's name and date.

3. Collection of Pubic Hair Combing: The new coarse-tooth comb provided should be used to comb any loose hairs or debris from the pubic region onto the white paper towel. Place the paper towel under the patients; comb the pubic area onto the paper towel. The comb and debris should be folded in the paper towel and the paper towel placed in the envelope. Seal and initial.

4. Collection of Vaginal Swabs: Saturate four (4) sterile cotton swabs from the vaginal pool below the cervix. DO NOT ASPIRATE. Allow the swabs to dry then place the swabs in their envelope. Seal and initial.

5. Collection of Cervical, Oral and/or Anal Swabs: If the circumstances of the case indicate, collect cervical, oral, and/or anal samples in the same manner as Step \#4. Note: Cervical swabs should be collected if the time between incident and exam is 24 hours or greater.

6. Collection of Oral/Buccal Swab Standard: Have patients rinse the mouth and wait 15 minutes before obtaining this sample. Using two (2) sterile cotton swabs, rub the inside of the cheek ten (10) times with an up and down motion. When dry, place the swabs into their envelope. Seal and initial.

\section{Disposition of Kit:}

- $\quad$ Be sure that each item is tape-sealed, initialed and returned to the kit.

- $\quad$ Be sure the information sheet is completed and returned to the kit.

- $\quad$ Seal the kit with tape and initial.

- $\quad$ If the kit is not Immediately turned over to a Law Enforcement Officer, please refrigerate.

(Florida Office of the Attorney General, 2015). 